\title{
„BECSÜLD MEG, BIZ’ A MESTEREKET!” - MÓDSZERTANI ÉS HISTORIOGRÁFIAI GONDOLATOK VÉKÁS LAJOS TUDOMÁNYTÖRTÉNETI KÖNYVE NYOMÁN
}

https://doi.org/10.51783/ajt.2021.3.01

\author{
A magyar hagyományok megőrzése, \\ a magyar érzésnek, gondolatnak, \\ tudásnak továbbfejlesztése [...]" \\ Idézet: Vékás Lajos $(1930)^{1}$ \\ „Verachtet mir die Meister nicht; \\ und ehrt mir ihre Kunst!” \\ Idézi: Vékás Lajos (2019)²
}

Vékás Lajos Fejezetek a magyar magánjogtudomány történetéből ${ }^{3}$ címü könyvében a tudománytörténet-irás személyközpontú módszerének alkalmazásával arra tett kísérletet, hogy igazolja: az elmúlt hat-hét emberöltö történelmi sorsfordulói ellenére a két évszázados hazai magánjogi gondolkodás szellemtörténeti szempontból homogén (kontinuus). A historiográfiai és a tudománytörténet-módszertani kritika, valamint a történetíró által kiválasztott nyolc jogtudós (Frank Ignác, Grosschmid Béni, Szászy-Schwarz Gusztáv, Szladits Károly, Nizsalovszky Endre, Világhy Miklós, Eörsi Gyula, Peschka Vilmos) vázolt életmüvének kritikai vizsgálata bizonyítja e törekvés helyességét. A személyközpontú történetírás eredményeit elemezve - és itt-ott a vázolt szempontok szerint kiegészítve - a mintegy kétszáz esztendő magánjogász gondolkodói generációinak (Vékás a kiemelt jogtudósokon túlmenően mintegy három tucat jurisperitust érint) horizontális és vertikális összekapcsolódásai nyomán világossá tehető az a hálózatszerủ rendszer, amely a paradigmaváltó történelem sodrában is megtartotta magánjogtudományunk folyamatosságát és - ezen túl annak folytonosságát is.

* Habilitált egyetemi docens, Pécsi Tudományegyetem Állam- és Jogtudományi Kar Polgári Jogi Tanszék, 7622 Pécs, 48-as tér 1. E-mail: benke.jozsef@ajk.pte.hu.

1 Természetesen a mű Szerzőjének nagyatyjáról, Vékás Lajos (1880-1962), kolozsvári ítélőtáblai elnökröl, az erdélyi kultúra örzőjeként történelmi szerepet betöltött Minerva kiadóvállalat korábbi vezérigazgatójáról van szó, akit a Szerző vallottan az életpályáját alapvetően meghatározó személynek tekint. Idézet: Vékás Lajos: „Az első tíz év” Pásztortüz 1930/21. 473-474. Idézi: Tibori Szabó Zoltán: „Minerva - A közösség szolgálatában (1920-2018)” Korunk 2018/10. 54-55.

2 Hans Sachs záró monológjának (R. Wagner: Nürnbergi mesterdalnokok, III. felv.) kezdő sorait a Szerző műve mottójául idézi: „A mestereket meg ne vesd, művészetük megbecsüld!” (Saját ford.).

3 VÉKÁs Lajos: Fejezetek a magyar magánjogtudomány történetéből (Budapest: HVG-Orac 2019) 188 pp. ISBN 9789632584737. 


\section{PROLÓGUS}

Hazánk emberemlékezet óta leghidegebb tele 1939-ben köszöntött be. ${ }^{4}$ Különösen csípős, hideg szombat reggelre ébredhettek 1939. november 25-én Kolozsvárott is. Ezzel szemben pontosan nyolc évtizeddel később ugyanott a hajnali fagyos ködszitálást délre verőfényes napsütés és kora tavaszi, 12 Celsius-fokos meleg váltotta fel. ${ }^{5}$ A dátum és a helyszín e dolgozat ${ }^{6}$ tárgyát képező mű szempontjából is meghatározó: az ugyanis nyolcvan esztendő különbséggel csakúgy a Szerző, mint műve születésének napja s helye. Vékás Lajos a művét útjára bocsátó „Bevezetés”-t ugyanis Kolozsvárott, 2019. november 25-én jegyezte le.

„Omnia mutantur, nihil interit” - tartja Ovidius. ${ }^{7}$ Az időjáráshoz hasonlóan az emberi szellem eredményei is folytonosan alakulnak, utóbbiak azonban el nem enyésznek: évszázadok generációin át öröklődnek a tanítványok életművében. Igazolják ezt a mű tézisei is, és e közkeletű, mégis, mindenkiben a maga pályafutásának évtizedei nyomán saját élettapasztalatként is rendre újjászülető felismerés a Szerzőtől sem lehetett idegen műve megalkotása során.

A kötet, mely részben a Szerző egyes korábbi előadásai ${ }^{8}$ és tanulmányai ${ }^{9}$ felhasználásával, átdolgozásával és kiegészítésével készült, számos új és eredeti megállapítást vonultat fel, nagyfokú precizitással dokumentált és széles apparátusra - 170 oldalon 733 db lábjegyzet (ebböl kb. 60\% hivatkozó, 40\% magyarázó) - építkezik. Ez is mélységes tárgy-és ügyszeretetről tanúskodik. A „tárgy”-at jellemezze a kötet Wagnertől kölcsönzött mottója, az „ügy”-et pedig a Szerző nagyatyjának kilencven évvel ezelőtti, fent kiemelt szavai!

4 Így a KSH 1901. évtől regisztrált „időjárási szélsőértékek” táblájának adatai. Forrás: $h t t p: / / w w w$. ksh.hW/docs/hun/xstadat/xstadat_eves/i_met003.html? lang $=$ hu.

5 Forrás: https://www.timeanddate.com/weather/romania/cluj-napoca/historic?month=11\&ye$a r=2019$.

6 Recenzióként lásd Osztovits András: „Fejezetek a magyar magánjogtudomány történetéből Frank Ignáctól Vékás Lajosig - párhuzamos recenziók” Jogtudományi Közlöny (a továbbiakban: $J K$ ) 2020/9. 419-423.; KőRös András: „Tudomány és hagyomány. Gondolatok Vékás Lajos: »Fejezetek a magyar magánjogtudomány történetéből « címủ könyve kapcsán” Magyar Jog (a továbbiakban: MJ) 2021/1. 46-57.; HAmZA Gábor: „Vékás Lajos: Fejezetek a magyar magánjogtudomány történetéböl" Magyar Tudomány (a továbbiakban: MT) 2021/7. 975-982. https://doi. org/10.1556/2065.182.2021.7.12.

7 Metamorphoses XV, 165: „Mindenek változnak, semmi el nem vész...”.

8 Pl. Frank Ignác és a történeti jogi iskola a magyar magánjogtudományban, előadás a „Grosschmid Béni halálának 80. évfordulója okán tartandó emlékülés" c. konferencián (Visegrád, 2018. szeptember 7.).

9 A kizárólag a jogtudósokkal, de nem az életművek értékelésével összefüggésben vizsgált jogintézményi kérdésekkel foglalkozó dolgozatok közül lásd pl. „Grosschmid »Fejezetek kötelmi jogunk köréből « című müvének centenáriuma” $J K$ 1999/9. 361-367.; „Grosschmid szelleme és gondolatai az új Polgári Törvénykönyv öröklési jogi szabályaiban” MJ 2013/5. 257-264.; „Szladits Károly és magánjogi iskolája” $J K$ 2018/2. 72-77.; „Emlékezés Világhy Miklósra születésének századik évfordulóján” JK2016/12. 585-594.; „Eörsi Gyula” in VereBics János (szerk.): Eörsi Gyula Emlékkönyv. (Budapest: Magyar Közlöny Lap- és Könyvkiadó 2018) 27-42.; „Eörsi Gyula: a professzor és a jogtudós 1922-1992” JK 2017/10. 421-430.; „Eörsi Gyula és a Bécsi Nemzetközi Adásvételi Egyezmény” JK2012/2. 80-82.; „Eörsi Gyula. 1922-1992” JK 1992/5. 257-258. (nekrológ). „Magánjogi kérdések jogelméleti megközelitésben Peschka Vilmos műveiben” JK 2017/5. 197-209. [=Acta Facultatis Pol.-Iur. ELTE, Tom. LIII-LIV (2016-2017); Editio specialis in memoriam Vilmos Peschka]. 


\section{HISTORIOGRÁFIAI ÉS TUDOMÁNYTÖRTÉNET- MÓDSZERTANI ÉSZREVÉTELEK}

A tudománytörténet (a természettudományokon túlmutató, általános értelemben mint: „Wissensgeschichte” avagy „history of knowledge” ${ }^{10}$ ) az alkalmazott humántudományok esetében igen sajátos történettudományi müfaj. Különleges volta azonban csak fokozódik a széles absztrakciókat az alkalmazott tudomány pragmatikusságával szükségszerűen ötvöző, a politika-, társadalom- és gazdaságtörténeti tényekre és viszonyokra reflektáló, vagy éppen azokat előidéző normatív berendezkedéssel foglalkozó jogtudományi irányzat, a magánjogtudomány szellemtörténeti szempontú elemzésének esetében.

A tudománytörténet-írás és metodikája történetében (historiográfia) az ókor nagyszerű, közismert példáitól egészen a XIX. század végéig uralkodó módszer a tudomány s nagyobbrészt a természettudomány képviselője: a tudós életének, nézeteinek, hatásainak leírása volt. Ez a személyközpontú elemzés csak kivételesen emelkedett olyan, a „Ki volt az első?”-kérdésre alapproblémaként tekintő irányzatoknál ${ }^{11}$ magasabb szférákba, amelyek nézőpontjából már az egyes tudósok „iskolákhoz" sorolásánál összetettebb folyamatok is kirajzolódhattak. ${ }^{12}$ Egy évszázada azonban e módszer helyessége megkérdőjeleződött, és a XX. század közepére a tudománytörténeti módszer mibenlétéről komoly tudományelméleti vita alakult ki - ismét csak elsődlegesen a természettudományok körében. ${ }^{13}$

Ezek után mind általánosságban, mind a bemutatandó kötet kapcsán önként adódik a kérdés: vajon korszerủ módszer-e a nemzeti magánjogtudomány-történetet a vezető jogtudósok füzérszerű „történeteként” megírni? Meggyőződésem szerint: helyes, mégpedig bizonyos korrekciókkal. Ugyanis a mai fogalmaink szerinti magánjogi tárgyú gondolkodás története európai, kontinentális léptékben egy többezer éves szellemtörténeti komplexum, s ez nem azonos a modern értelemben vett, alig kétszáz esztendős magánjogtudomány történetével. A „köztörténeti” folyamatokban ennyi idő alatt nem történt oly sok, magánjogi szempontból releváns politikai, társadalmi, gazdasági fordulat, amely átláthatatlanná fragmentálta volna a par excellence magánjogi viszonyokról és az azok szabályozásáról, valamint elméletéről, dogmatikájáról folyó, modern értelemben vett, absztraháló tudományos gondolkodás történetét. Ezért egyenesen kézenfekvő, hogy e történetírás hídpillérei a „tárgyat létrehozó” tudósok (életük, eredményeik, hatásaik) legyenek.

10 Olivier Darrigol: „For a History of Knowledge” in Kostas Gavroglu - Jürgen Renn (ed.): Positioning the history of science (h. n.: Springer 2007) 33-34., https://doi.org/10.1007/1-4020-5420-3_5.

11 Lásd Dirk Rupnow (Hrsg.): Pseudowissenschaft. Konzeptionen von Nichtwissenschaftlichkeit in der Wissenschaftsgeschichte (Frankfurt am Main: Suhrkamp Taschenbuch Verlag 2008) passim.

${ }^{12}$ A „Rechtswissenschaftsgeschichte” kifejezéshez lásd pl. Jens Eisfeld: Erkenntnis, Rechtserzeugung und Staat bei Kant und Fichte (Tübingen: Mohr Siebeck 2015) 130-132. Vö. Maximilian HERBERGER: „Rechtswissenschaftsgeschichte - eine neue Disziplin?” Rechtshistorisches Journal 1984/3. 150-168. Forrás: http://archiv.jura.uni-saarland.de/projekte/Bibliothek/text. php? id=127\#Anm.

13 Lásd Helge Kragh: An Introduction to the Historiography of Science (Cambridge: Cambridge University Press 1990) 1-20., 41-51., 150-159. és 168-174. 
Jóllehet Vékás Lajos könyvében elsősorban nem tudományfilozófiai és történettudományi alapon, hanem inkább pragmatikusan közelítette meg e kérdést, a kötet bevezetésében (9-11. o.) számos olyan - fentebb anticipált - korrekcióra utal, amely alátámasztja ama törekvése helyességét, hogy a magyar magánjogtudomány kétszázados történetét - a mű címe szerint „fejezetszerűen” - az általa legjelentősebbnek ítélt jogtudósok személyén, életpályáján, munkásságán és ezek aktualizálásán, értékelésén keresztül közelítse meg. Melyek tehát a jogtudós-központú történetírási módszernek azok a korrekciói, melyek meglétében a kényes tudományelméleti igényekhez képest is igazolható e módszer helyessége?

Bár a historiográfia egyik alaptétele, hogy a történeti objektivitást alapvetően befolyásolja a történetíró személye, a hazai jogtudósok legjelentősebb képviselőinek kiválasztása tekintetében többé-kevésbé már kialakult az utókor objektívként elfogadható értékítélete, amelyet a Szerző is - kifejezetten utalva a válogatás szubjektivitásának kockázataira és előnyeire is - túlnyomórészt magáévá tett a névsor meghatározásakor. Noha Frank Ignác, Grosschmid Béni, Szászy-Schwarz Gusztáv, Szladits Károly, Nizsalovszky Endre, Világhy Miklós, Eörsi Gyula és Peschka Vilmos nevét olvasva eszébe juthatnak az olvasónak akár a XIX., akár a XX. századból a széles értelemben vett magánjog további jeles hazai alkotói ${ }^{14}$ (olykor valódi szellemóriásai) is, e nyolc jurisperitus - közülük az utolsó négy a Szerző kortársa - tudománytörténeti jelentőségének túlértékeléséről mégsem lehet szó. A terjedelem szempontjából „dobogósok” sorrendben: Grosschmid, Frank, Peschka. A legstrukturáltabb fejezetek: a Grosschmidröl és a Világhyról szóló rész hat-hat alfejezettel. ${ }^{15}$ A történetíró személyénél maradva ki kell emelni: nemcsak azért szerencsés, hogy legnagyobb magánjogászaink méltatását és értékelését Vékás Lajos végezte el, mert e kényes feladatban „a toll mindkét végén” equilibrium alakulhatott ki, hanem azért is, mert a Szerző személyénél fogva hiteles adalékokkal szolgálhat az ún. „oral history” műfajában is nemcsak saját kortársai (lásd alább), hanem a források láncolata nyomán még az évszázados elődök tekintetében is. ${ }^{16}$

A Szerző „saját értékrendje szerint szelektált és minősített, saját értékmérője alapján hangsúlyozott vagy hagyott háttérben témákat vagy mozzanatokat. Valószínű, hogy egy későbbi kor kritikusa éppen ezt a szemléletmódot fogja egyoldalúnak találni és bírálat tárgyává tenni. Ezt a „veszélyt” azonban a történetíró legjobb igyekezete mellett sem kerülheti el, hiszen nem tud kibújni a kora és személyisége varrta gúnyából, akarva-akaratlan vállalnia kell annak szorítását." (9. o.; a továbbiakban a müből vett idézetek, hivatkozások helyének megjelölése simili modo a szöveg után

${ }^{14}$ Betủrendben lásd pl. (keresztnevek csak az egyértelműsítés végett feltüntetve): Almási, Apáthy, Asztalos, Beck, Benedek Károly, Bozóky, Dell’Adami, Fodor, Herczeg, Huszty, Kelemen Imre, Kelemen László, Kemenes Béla, Kolosváry, Kuncz, Mádl, Márkuss, Marton, Meszlény, Novotni, Ökröss, Petrik, Sárándi, Somló, Suhayda, Szalay, Szászy Béla, Szászy István, Thirring, Ujlaki László, Újlaki Miklós, Villányi (Fürst), Weiss, Wenzel, Zoltán Ödön stb.

${ }^{15}$ Peschkáról öt; Frankról, Szladitsról (a magánjogi iskolával), Nizsalovszkyról és Eörsiröl négynégy, Szászy-Schwarzról három alfejezetben szól. Az albeosztások rendje pedig Grosschmidnál és Peschkánál a legösszetettebb.

${ }^{16}$ A Szerző pl. Grosschmidről Beck Salamon olyan szavaival is szólhat bizonyos kérdésekben, melyeket az bő fél évszázaddal ezelőtt a Szerzőnek címzett. Vö. 54. o. 113. lj. 
zárójelben szerepel). Ezt az önkritikát azonban a Szerző később maga is korrigálja, s azt megerősíti a könyv tartalmának részletes vizsgálata is: jócskán merít a kortársak értékítéleteiből, ${ }^{17}$ ezáltal elkerüli az általa felvetett torzító hatást. A névmutató (183-185. o.) 171 nevet tartalmaz, közülük a bemutatott jogtudósok olyan kar- és kortársainak száma, akik megállapításait tudományunk vezető képviselői életpályájának illusztrációjaként közvetlenül fel is használja: mintegy negyvenöt fö. A régi atyamesterek tekintetében vallottan „nem alkot új kánont”, hanem csupán „megerősíti az évszázados közmegegyezést” - jóllehet még hagyománytiszteletből sem mond le arról, hogy munkásságukat kritikai elemzés tárgyává tegye, a megszilárdult opinio communis-t kiegészítse, azt új optikában tüntesse fel.

Az a tény, hogy a Szerző saját kortársairól, mestereiről, kollégáiról a kapcsolat „személyes jellege és a történelmi távlat hiánya” (9. o.) mellett rajzol pályaképet, inkább jelent helyzeti előnyt (az egyes személyiségjegyek megőrzését), mintsem hátrányt, miként azt a Szerző is leszögezi. Ennek érdekében a személyes - az olvasók számára valószínüleg igen értékes - visszaemlékezéseket minden esetben elkülönítette a pályaképtöl.

A magánjogtudomány kétszáz éves történetének alakulásáról nem szisztematikus és átfogó, mindenesetre „reális benyomás” kialakítását tűzi ki célul a Szerző nemcsak a vezető jogtudósok pályaívének megrajzolása, hanem tudományos eredményeik szakmai értékelése által is a „tudatosan vállalt egységes megközelítés és homogén szemlélet" vezérfonalát követve.

A Szerző téziseként is felfogható, hogy a jogtudósportrék olykor szükségszerüen hézagos vagy éppen átfedéseket mutató egymásutánját az a kontinuitás fogja össze koherens rendszerré, amely a hazai magánjogtudomány történetének szinte egyedülálló sajátja: oly történeti kataklizmák sem voltak képesek felszabdalni álláspontja szerint ezt a folytonosságot, mint például a szocialista átalakulás, illetőleg, tehetnénk hozzá, további nagy kríziseink sem. Érdemes volna megvizsgálni, vajon e kontinuitásnak nem éppen az az utókor előtt olykor lemaradásnak tetsző körülmény volt-e az alapja, hogy hazánkban 1960-ig nem volt kodifikált magánjog...

Idetartozik az az alapvető módszertani kérdés, hogy a tudománytörténet tényeit és föleg: személyeit a szellemtörténetnél szélesebb történeti kontextusba helyezze a történetíró. A Szerző vallja, és számos kényes esetben részletes elemzés tárgyává is teszi, hogy jóllehet a magánjog és tudománya a politikumtól a legkönnyebben függetlenedni képes területe a jog világának, mégis, e tudomány művelői sem határolódhattak el koruk „politikai áramlataitól és kényszereitől”. (10. o.) Leszögezi, hogy a legkiválóbbak ideológiához való, elvárt „alkalmazkodása” az életművet eltorzító hatást eredményezhet még akkor is, ha a zsargon felmondása csupán „kényszerüen felvett mimikri" (11. o.) volt.

Az életművek értékelése, csak az adott korszak vezető eszmeáramlataiba történő belehelyezkedés - valóban embert próbáló - szellemi feladata útján lehetséges. A fent említett kontinuitást megerősíti a Szerzőnek az a módszertani tézise is, hogy

17 Pl. Frankról a Szerző Grosschmiddal, Szladitscsal, Eckharttal, Paulerrel, Asztalossal, Peschkával alkot képet. 
a bemutatott jogtudósok munkásságában kortársaik eredményei is reflektálódnak, így a válogatás szubjektivitása tompítható - s tegyük hozzá, e hatás megerősödve, mintegy hálózatszerűen halad tovább az évtizedeken át egészen napjainkig. ${ }^{18}$

Fontos eredménye (de nem: eszköze) a tudománytörténet-írásnak mindezeken túlmenően az eredmények aktualizálása is: a Szerző imponálóan mutat ki olykor nem kézenfekvő, sőt, időben és tematikusan meglehetősen távolinak tűnő párhuzamokat mind a jogintézményi szint, mind a nagyobb elméleti absztrakciók világából. ${ }^{19}$ Emellett arra sem sajnálta a fáradságot, hogy egy-egy történeti értékủ probléma kapcsán még napjaink fiatalabb kutatóinak munkásságából is válogasson színvonalas analógiákat.

\section{VÁZLATOK, MEGJEGYZÉSEK, ADALÉKOK ÉS JEGYZETEK ${ }^{20}$}

Magánjogtudományunk előző két évszázadának történetét Vékás Lajos nyolc jogtudós és „holdudvaruk” bemutatásával rajzolja meg minuciózus alapossággal. A Szerző megállapításainak tézisszerű összefoglalói a „Fejezetek” rendszerét követi kisebbnagyobb kiegészítésekkel, szakmai és nem szakmai jegyzetekkel, hozzászólásokkal, észrevételekkel. Mindez a legkevésbé sem helyettesíti a mű gazdag - számos esetben a lábjegyzetekben „elrejtett” - tartalmát, a Szerző saját, az életművek tematikájában kifejtett jogi okfejtéseit, és nem adhatja vissza a letisztult, gördülékeny, sokhelyütt irodalmi stílust sem: a Szerző nem áldozza fel anyanyelvünk szépségét a szakszerüség oltárán.

\subsection{FRANK IGNÁC}

Frank Ignác (1788-1850; 13-30.) $)^{21}$ életművét a mủ a pesti egyetem oktatástörténetébe ágyazza be, utal a jus patrium (az ún. „hazai jog”, a rendi magánjog) institucionális oktatásának kezdeteire, s hangsúlyozza a nemzeti nyelven történő oktatás

18 Álláspontja szerint ugyanakkor Frank és Grosschmid esetében „a kisugárzó hatás egyértelműen felülmúlja a másoktól felvett energiát" (idézet: 10. o.).

${ }^{19}$ Elöbbire pl. a kötelesrész szabályozásának kérdése Grosschmidtől a hatályos kódexig, utóbbira a kodifikáció alapkérdése az ún. Savigny-Thibaut-vitától napjainkig.

${ }^{20} \mathrm{Az}$ alábbi alpontokban a jogtudósok neve után zárójelben szerepelnek a születési-halálozási évszám mellett a Vékás-kötet vonatkozó fejezetének oldalszámai és lábjegyzetbe helyezve a könyv apparátusában nem hivatkozott szakirodalom. Az egyes jogtudósok e fejezetben tárgyalt - általában közismert - műveinek könyvészeti adatait lásd a Vékás-féle mủ itt hivatkozott locusaiban.

${ }^{21}$ Lásd Dorottya Lipták: „Mäzene und Mäzenatentum im Dienste der Nation und der Hauptstadt” in Frédéric BARBIER - István MoNoK (ed.): Les Bibliothèques centrales et la construction des identités collectives (Leipzig: Leipziger Universitätsverlag 2005) 101-124., különösen: 101-106.; HoRvÁTH Pál: „Frank Ignácz és a történeti jogi iskola” Acta Facultatis Pol.-Iur. ELTE 1994. 133-151.; Uö: „Frank Ignácz emlékére születésének 200 éves évfordulója alkalmából” Acta Facultatis Pol.-Iur. "ELTE 1990. 132-140.; SzaBó Béla: „Frank, Ignác” in Michael StolleIs (Hrsg.): Juristen. Ein biographisches Lexikon von der Antike bis zum 20. Jahrhundert (München: Verlag C. H. Beck ${ }^{22001)}$ 221-222. [= 1995. 214-215.]. A régebbi szakirodalomból pl. SARLós Márton: „Frank Ignác bécsi tevékenysége és halála. Halálának százhuszadik évfordulója alkalmából” MJ 1970/4. 245. 
jelentőségét mind Kelemen Imre, mind Frank tankönyve tekintetében. Ehhez képest az objektivitás kedvéért érdemes lenne pontosan kimutatni, hogy Huszty István (?1710-?1772) egri jogakadémiai tanár sokszor kiadott, több helyütt tankönyvként előirt és az igazságszolgáltatásban is használt, egyes részletkérdésekben európai léptékben is az úttörők közé sorolható magánjogi kézikönyve ${ }^{22}$ milyen mélységben „őrződött meg” a pesti tanszék első oktatási anyagainak szövegében.

A Szerző az életpálya vizsgálatánál homályosan utal a Kelemen Imre „utódlása” körüli, nem zökkenőmentes helyzet kapcsán arra, hogy az udvarnál ekkor a tudományossággal szemben más tényező, nyilvánvalóan a politikai beállítottság nagyobb súllyal eshetett a latba. Az uralkodó ugyanis nem a Kar által elsődlegesen támogatott Kelemen-tanítványt, az akadémikus Szlemenics Pált nevezte ki utódul. A pesti - és tegyük hozzá: a pozsonyi (!) - egyetemi kinevezésnek a kötetben már-már talányosként említett sikertelensége mögött mindazonáltal egészen konkrét politikai indokok álltak. ${ }^{23}$ Vékás ezen túlmenően Eckhartra hivatkozva úgy véli, az utókor igazolta a király döntését. Ennek az ítéletnek az elfogadásához ugyanakkor azt a lehetőséget eleve ki kellene zárni, hogy a Tudós Társaság első jogász tagjának ${ }^{24}$ teljesítménye, aki latinul, magyarul és németül tucatnyi kötetben kifejtette a hazai jog szinte teljes spektrumát mind élő jogi, mind történeti szemléletben, legalább elérhette volna Frankét.

Paulerrel szemben, Peschka nyomán Frankot mint iskolához, irányzathoz nem tartozó, autonóm gondolkodót jellemzi, és a Jheringtől függetlenül „érdekkutatóvá lett” Grosschmiddal állítja párhuzamba utalva arra, hogy például a kodifikációellenesség inkább a konzervativizmus, mintsem a historische Rechtsschule tanai követésének a következménye. A részletek tekintetében ugyanakkor Pólay Elemér - elmélyült, de a korabeli zsargont nem nélkülöző - fejtegetései ${ }^{25}$ alapos eligazítást nyújtanak: Frank szellemtörténeti autonómiáját tekintve Pólay ugyan a Szerzővel egyező következtetésre jutott, mégis, a függetlenség oksági hátterében tételesen cáfolta a franki munkássággal kapcsolatban uralkodó nézetek jelentős részét.

22 Stephanus Huszty: Jurisprudentia practica seu commentarius novus in jus Hungaricum. H./é. mult. A szerző a bona fides objektív és szubjektív alakzatának elkülönítésében európai szinten is a legkorábbiak közé tartozik. E tekintetben még Frank könyve is visszalépés Husztyéhoz képest. Mindezekhez részl. lásd FöLDI András: A jóhiszemüség és tisztesség elve. Intézménytörténeti vázlat a római jogtól napjainkig. [=Publicationes Instituti Iuris Romani Budapestinensis fasc. 9] (Budapest: ELTE ÁJK 2001) 34. és 76-79.

23 „Szlemenics 1819-ben megpályázta a pesti egyetemen Kelemen Imre nyugalomba vonulásával megürült magánjogi katedrát, de nem járt sikerrel. Néhány év múlva, 1827-ben ismét pályázott a pesti professzorságra, amelyet minden egyetemi és kormányzati szerv támogatott, de az uralkodó mégsem nevezte ki. Ennek hátterében a titkosrendőrség állott, amely információi alapján I. Ferenc nem találta megbízhatónak az egyetemi katedrára, helyette Frank Ignácot nevezve ki. Később a pozsonyi akadémia vezetői tisztségét, a prodirektori állást sem sikerült megszereznie. Az 1832-es pályázatokat véleményező titkosrendőrségi vélemény szerint - bár a magyar hatóságok ismét őt tartották legalkalmasabbnak - nem engedhető meg, hogy Szlemenics kapjon kinevezést, mivel a professzori és az akadémiai vezetői állás ugyanazon személy általi betöltése összeférhetetlen, továbbá a hallgatókkal való családias kapcsolata és felesége magatartása miatt sem érdemes a tisztségre." NÁNÁsı László: „A magyar jogtudomány első akadémikusa, Szlemenics Pál (1783-1856)” MT 2014/1. 32-41., 36.

${ }^{24}$ NÁNÁSI (23. lj.) 32.

25 Pólay Elemér: „A pandektisztika és hatása a magyar magánjog tudományára” Acta Univ. Szeged. Acta Jur. et Pol., Tom. 23, Fasc. 6. (Szeged: SZTE ÁJK 1976) 91-109. 
Frank Ignác életművét kézenfekvő módon „A közigazság...”-on keresztül értékeli, mégpedig a XXI. századi jogtudós szemével. E sajátos nézőszög - a későbbiekhez hasonlóan - érdekfeszítő elemzéseket és aktualizálásokat eredményez (az ingatlankézizálogjog, a helyettes örökös és a maradék-utóörökös nevezése stb. körében), s az utóbbit a Szerző olykor az olvasóra is rábízza (így pl. a res corporales mellett a jogokat és követeléseket magában foglaló franki „jószág”-fogalom és a „vagyontárgy” Ptk.-beli definíciója esetében). Frank egyes téziseinek jelentőségét a Szerző itt-ott talán kissé túlértékeli: például a normaértelmezés kapcsán Frank álláspontja csupán Celsus recepciója; ${ }^{26}$ a normaértelmező szokás szerepe esetében nem lép túl Pauluson; ${ }^{27}$ a visszaható hatály általános tilalma kifejtésének jelentősége pedig azért esik el, mert az csupán régi, nagy elődök - pl. Démoszthenész Timocrates elleni beszéde, II. Theodosius császár rendelete (C. 1, 14, 7; a. D. 440), Mátyás 1486. évi VI. törvénye (70. cikk) - nyomán jár. ${ }^{28}$ Érdekes, hogy a Szerző Frank szokásjogi jogképződés primátusát kifejtő tézise körében a szokásjog és a jogszokás fogalmakat szinonimaként ${ }^{29}$ kezeli. (19-20. o.)

Frank kapcsán a fejezet legkiemelkedőbb része minden bizonnyal az akadémiai székfoglaló előadás („Ősiség és elévülés”) anyagának a korábbi szerzőkhöz (beleértve Pólayt is) képest mélyebb analízise mind az életmű, mind az ideológiai beállítottság szempontjából: a kortársak értékítéletére is figyelve a Szerző az objektivitás talaján marad, és mesterien ötvözi a konkrét mű szakmai elemzését és annak az életmű egészében történő elhelyezését az „emberi tényező” értékelésével. (2630. o.) Abból, hogy a társadalmi bajok hitelszűke miatti eszkalálódásának megoldását Frank nem az ősiség eltörlésében, hanem az elévülés hibás rendszerében látta (melynek reparálása a birtokviszonyok kaotikus helyzetét megszüntetve alkalmassá tenné az ingatlantulajdont a hitelfedezeti funkció betöltésére), a Szerző kifinomult érzékkel állítja elénk Franknak a „társadalmi haladás” eszméjét a szakszerüség, de nem az ideológia felől megközelítő - a jövő súlyos bizonytalansága miatt az életnek is hátat fordítani képes - alakját.

\subsection{GROSSCHMID BÉNI}

Grosschmid Béni (1852-1938; 31-63. o.) ${ }^{30}$ személyét a Szerző a polgári magánjog és tudománya kialakulásának szellemtörténeti környezetében helyezi el, hangsúlyozva a feudális magánjogi kötöttségek lebontásának szervetlenségét és következet-

${ }^{26}$ Vö. D. 1, 3, 17 Celsus libro 26 dig.

27 Vö. D. 1, 3, 37 Paulus libro primo quaest.

${ }^{28}$ Lásd már TÉLFy Iván: „Adalékok az attikai tökvénykönyvhez” Értekezések a nyelv- és széptudományok köréből (1.2) (Pest: Eggenberger 1868) 12-13. Forrás: http://real-eod.mtak.hw/293/.

${ }^{29}$ Vö. újabban pl. HoмoKI-NAGY Mária: „A szokásjog hatása a magyar magánjog fejlődésére” in NAGY Janka Teodóra (szerk.), Szokásjog és jogszokás. I. kötet (Szekszárd: PTE KPVK 2016) 165-175.; VARGA István: „Egy jogszokás intézményesülése: törvénytelen születésű gyermekek tartása iránti perek a két világháború között” in NAGY, i. m. II. kötet, 335-354.

30 JuHÁsz Ágnes (szerk.): Grosschmid gondolatai és az új magyar Ptk. (Miskolc: Novotni Alapítvány 2013); Tóтн Ádám (szerk.): „Grosschmid Béni: Öröklött és szerzett vagyon.” Közjegyzői Füzetek - 
lenségét (31. o.), illetve a történeti jogi iskola visszahúzó hatását Wenzel, Suhayda, Zlinszky és Herczeg munkásságára, valamint Grosschmid normatani művére utalva.

Tartalom és forma tekintetében Grosschmid autonómiáját - sőt: autarchiáját és az Interessenjurisprudenztől való függetlenségét az „érdek” jogalkotási és jogalkalmazási fogalmának meghatározásával, és a nagy tanítvány, Szladits olykor tényszerű, olykor már-már személyi kultuszra utaló szavaival ${ }^{31}$ támasztja alá, és idézi Kuncz Ödön kudarcos Grosschmid-tanulmányozásáról szóló, önkritikus vallomását (33. o. 14. lj.) is.

A Szerző egyetért Szladitscsal abban, hogy a zseniális jogtudós munkássága nem csupán megalapozta a modern hazai magánjogi gondolkodást, hanem lényegében megteremtette a modern magyar magánjogot. Hatása napjainkig terjed, hiszen az a XXI. századi Ptk.-kodifikáció egyes módszertani és intézményi előkérdéseit is befolyásolta. A nehéz megközelíthetőséget a nyelvi kifejezésmód sajátosságai mellett - Szladits véleményét elfogadva - Grosschmid induktív módszerében látja: a vagyonjog hatalmas anyaga az egyediből felgöngyölítve az olvasótól a mű alkotójához fogható elmét követel. Érdemes lett volna talán utalni még arra, hogy Grosschmid a lassan egy évszázada megjelent „Werbőczy és az angol jog”32 c. műve alapján a hazai történeti jogösszehasonlítás egyik előfutárának is tekinthető.

Grosschmid munkásságának napjaink magánjogtudományára kifejtett hatásait három kérdés izgalmas elemzése útján igazolja (az első és a harmadik kérdéskör kifejtése oly gazdag, hogy bemutatásuk is önálló tanulmány tárgya lenne): a „Fejezetek” hatásai a kauzális tulajdonátruházási rendszer és az átadás (traditio) aktustani természetének meghatározásában; ${ }^{33}$ a nagyváradi jogakadémia 1883. évi

Studia Notarialia Hungarica 8. évf., 2008. Lásd továbbá GöRöG Márta: „Grosschmid Béni (18511938)” Forum: Acta Jur. et Pol. 2020/1. 227-240; LANDi Balázs: „A jogellenesség, mint a deliktuális felelősség tényálláselemének jelentősége és jelentés-változásai Grosschmid Béni, Zachár Gyula és Kolosváry Bálint elméleti írásaiban” in Cseni Zoltán et al. (szerk.): (L) ex Cathedra et Praxis. Ünnepi kötet Lábady Tamás 70. születésnapja alkalmából (Budapest: Pázmány Press 2014) 157-185.; Szalma József: „Grosschmid Béninek a magyar polgári jogi jogtudományban kifejtett elméleti és törvényhozási munkásságáról” Advocat (Miskolc) 2014/1-2. 51-52.; VöRös Imre: „Grosschmid - reloaded. Tudósítás a jogállamiság határvidékeiről” Jogelméleti Szemle (a továbbiakban: JESZ) 2012/3. 118-137.; Szabó Béla: „Grosschmid (Zsögöd), Béni” in: Stolleis, i. m. ${ }^{2} 2001.264-265={ }^{1} 1995$, 256 257.; Izsó Krisztina: „Grosschmid évforduló” JK 1999/7-8. 351-354.; Weiss Emília: „Grosschmid családjogi és öröklési jogi munkásságáról” $J K$ 1999/11. 475-479. A régebbi irodalomból lásd: AszTALos László: „Grosschmid Béni helye a magyar civilisztikában” ELTE Állam-és Jogtudományi Kar Actái 1984. 197-216.; Almási Antal: „Grosschmid Béni” Jogállam: jog-és államtudományi szemle (a továbbiakban: JÁ) 1921/10. 366-369.; BöLÖNY József: „Grosschmid Béni mint közjogász” Magyar Közigazgatás 1938/48. 1-2.; VILlÁNYI (FüRST) László: „Grosschmid Béni” JÁ 1938/7-8. 265-272.

${ }^{31}$ E hangvételt a Szerző - nem túl kíméletesen, bár átvitt értelemben tényszerűen - később maga is „hozsannázó”-ként aposztrofálja (lásd 81. o. 1. lj.); vö. ugyanakkor: Mt 21:9,15; Mk 11:9-10; Jn 12:13; Lk 18:39.

32 Budapest: Franklin 1928. A mű korabeli recenzióit lásd ZaLÁn Kornél sorozatában: JK (régi sor.) 64. évf.: 1929/8. 77-78.; 1929/10. 97-99.; 1929/11. 106-107.; 1929/12. 118. Újabban lásd SÁNDoR István: „Grosschmid és az angol jog” in JuHÁsz Ágnes (szerk.): Grosschmid gondolatai és az új magyar Ptk. (Miskolc: Novotni, 2013) 135-145.

33 A Szerző nagy részletességgel és dogmatikus alapossággal mutatja be a traditio értelmezésének két alapvető iránya - reálaktus az ügyletegység elve szerint, vagy az elkötelező ügylettől elkülönült dologi hatályú rendelkező ügylet - közötti különbségeket és azok jogi hatásait. 
tanévnyitóján elmondott, „A kereskedelmi jognak különválásáról” című, profetikusnak mondható, naprakész - ti. a fél évvel korábban hatályba lépett svájci kötelmi törvény monista koncepcióján alapuló - előadásának reflektálódása a hatályos magyar Ptk. monista felfogásában; illetve a XIX. század végi örökjogi kodifikációs előmunkálatok (magántervezet a törvényes öröklésröl, hivatalos tervezet az öröklési törvény életbe léptetéséröl, illetve az örökösödési törvénytervezet bírálata) és a nagyszabású, húsz esztendősen írt, Sztrokay-díjas dolgozat (1873) hatásai a 2013. évi kódex öröklési jogára az özvegyi jog, az ági öröklés és a kötelesrész intézményének rekodifikációja terén. ${ }^{34}$

A zeneértő Szerző izgalmas párhuzamot von a Bach-zene Mendelssohnnak köszönhető újjászületése ${ }^{35}$ és a grosschmidi opus magnum ezredfordulós reneszánsza között. (33. o. 13. lj.) A zárszóban pedig - amelyet akár a mindenkori „cupida legum iuventus”-nak is címezhetett volna ${ }^{36}$ - arra utal, hogy jóllehet a tudományos hagyaték az ifjú jurátusok számára nehezen megközelíthető, az mégis szellemi kincsesbányául kínálkozik. (63. o.) Tegyük rögvest hozzá: hasonlóan J. S. Bach előadó ${ }^{37}$ és befogadó számára egyaránt munkás, de a legmagasabb rendủ élvezetet nyújtó muzsikájához; „[a]bban található a legtöbb mélység, eredetiség, önállóan búvárkodó s teremtő szellem, [...] észjárása [...] zseniális, nyelve erőteljes" ${ }^{38}$ - nem, e sorok nem Bachot méltatják, hanem azok a még szinte „tinédzser” alkotó (prodigium?) említett pályadíjának indokolásából valók, amelyen az MTA főtitkára, Arany János kézjegye áll.

\footnotetext{
${ }^{34}$ Az özvegyi jogról szólva a Szerző a kettős öröklés fenntartása tekintetében a jogtörténeti változásokat azok indokain keresztül világítja meg, a releváns társadalmi (demográfiai, családi) és gazdasági (hagyatékok mérete és összetétele) átalakulásokat éles szemmel foglalja össze és tárja az olvasó elé. A Szerző a releváns etikai és érzelmi kérdésekről is Grosschmid „hangján szól”, így pl. a gyermekvállalási kedv és az özvegy állagöröklésének mértéke közötti, állítólagosan előnytelen összefüggéséröl (54. o.). Az ági öröklés körében annak tárgyi és időbeli terjedelme, a jogutódlás szinguláris jellege, illetve a bizonyítási teher szabályozása és ezek háttere az összehasonlító jogi és komparatív szociológiai elemzése tárgya. A kötelesrész terjedelmével, indokával és a kitagadással (durva hálátlanság, előzetes megbocsátás stb.) foglalkozó fejtegetések hasonló mederben zajlanak. A Szerző Grosschmiddal vallja: „[...] mindig jobb, ha mentől erősebb [a] családos érzésben a természet szava; [...] mindig jobb, ha a közel vérek közt jog rende nem kell, [...] szeret is a jog távol maradni a tértől, hol a természet ez érzelmek uralmát javallja, [...] S csak ha az érzület odabenn elfajul, csak ha segítség kiáltása hallik az érzelem birodalmából, nyújtja be osztó kezét visszaélés ellen." (59-60. o.).

${ }^{35}$ A kánon szerint az ún. Bach-reneszánsz 1829-ben a Máté-passió Bach halála utáni első előadásával kezdődött meg: egy rövidített verziót (áriákat és korálokat hagytak el) adott elő a berlini SingAkademie, majd a frankfurti Cecília Egyesület Felix Mendelssohn-Bartholdy vezényletével. Az első előadásokhoz lásd Joshua RIfkin: „The Chronology of Bach’s Saint Matthew Passion” The Musical Quarterly 1975/3. 360-387., https://doi.org/10.1093/mq/lxi.3.360.

36 Jusztiniánusz tankönyvének dedikációja, jelentése: „a törvényt [ismerni] vágyó ifjúságnak” (Inst. Prooem.).

37 E tanulmány szerzője e megállapítást a Magnificat és egyes egyházi kantáták tenor szólóinak koncertelőadása után talán joggal teheti meg.

${ }^{38}$ Idézi a Szerző, lásd 58. o.
} 


\subsection{SZÁSZY-SCHWARZ GUSZTÁV}

Szászy-Schwarz Gusztáv (1858-1920; 65-80. o.) ${ }^{39}$ közismert hallgatói, oktatói, kutatói és kodifikátori pályaképének megrajzolása után a Szerző a jogi személy elméletének tárgykörébe tartozó, önmagában logikailag koherens egész és a nemzetközi diskurzusba eminenter beilleszkedett, jóllehet az álláspont magánjogi rendszer fogalmi apparátusának átfogó reformját igénylő volta miatt utóbb történeti értékűvé vált fejtegetéseit elemzi, és annak kritikáját a kortársak idézése mellett maga is vázolja.

Ezt követően a fejezet több mint a felét (69-76. o.) kiteszi Szászy-Schwarz Jheringről szóló munkájának ismertetése. Az olvasó azt várja, hogy SzászySchwarzról az általa Jheringnek állított „tükörben” kaphatunk majd reflektív, mégis részletgazdag képet. Azonban a lapokon haladva az író s az olvasó iránytüje is a nagy német jurista tudósi és emberi bűvkörébe lépve elveszti a pólust. A Szerző az Arany utáni - már az 1850-es években Arany mellett Erdélyi és Gyulai által is kíméletlenül ostorozott - epigonköltészettel állítja párhuzamba, hogy Savigny iskolája a követők tévelygése miatt „torzképévé fajult a mesternek”. (71. o. 35. lj.) Erre utal Szászy-Schwarz is Jhering „Geist”-ja nyomán. A zeneértő Szerző szép, történeti „ellenpontot” lát a jheringi „Geist”-nak a „Zweck im Recht” miatti előnytelen félbeszakítása és a Wagner-tetralógia (ti. a Siegfried és az Istenek alkonya) befejezését végül is meg nem gátló, de „intermezzo”-nak semmiképp nem nevezhető, mintegy kilenc évre rúgó periódusa között, amely alatt elkészült a „Trisztán és Izolda”, valamint „A nürnbergi mesterdalnokok”. Ezt követően Jhering további, kisebb lélegzetủ mủveinek Szászy-Schwarz-féle osztályozását foglalja össze kiemelve a culpa in contrahendo „felfedezés”-jellegét, s erre visszavezetve azt, hogy a tanítvány mintha még nem ismerte volna fel a - jog világában nem gyakori - „találmány” ${ }^{40}$ valódi jelentőségét. Izgalmas, az idealizmust naivitásként kezelő napjainkkal szemben élesen kritikus aktualizálásra használja fel a Szerző Jhering „Kampf ums Recht” címü szatirikus mủvének szászy-schwarzi elemzését. (75-76. o.)

Az öröklési jog kodifikátora érdemeinek értékelését (76-79. o.) követi a SzászySchwarz által igen kedvelt müfaj, a tanulmány néhány jelentős darabjának puszta említése. Bizonyára minden olvasó kíváncsi lett volna a Szerző utolsó magyar pandektajogász - Szladits, Marton és Beck mestere - normatanáról, ügylettanáról

${ }^{39}$ Az újabb szakirodalomból lásd Leszkoven László: „»Úszó határok a jogban «-Szászy-Schwarz Gusztávra emlékezve” MJ 2020/12. 725-732.; LÁBADY Tamás: „Schwarz Gusztáv - A »magyar Jhering «mint magánjogász" in Frivaldszky János - PoKol Béla (szerk.): Rudolf von Jhering és jogelméletének hatása. (Budapest: PPKE JÁK 2011) 221-225.; SzABADFALvi József: „Szászy-Schwarz Gusztáv szerepe a hazai Jhering recepcióban: Jogbölcseleti megközelítés” in FRIVALDSZKY - PoKoL, i. m. 225-247.; = JK 2010/3. 115-123.; GöNczI Katalin: „Gusztáv Szászy-Schwarz” in StolLeIS, i. m. ${ }^{22001.616-617 . ~ A ~ r e ́ g e b b i ~ i r o d a l o m b o ́ l ~ l a ́ s d ~ S z l a d i t s ~ K a ́ r o l y: ~ „ S z a ́ s z y-S c h w a r z ~ G u s z t a ́ v ” ~ J K ~}$ (régi sor.) 1920/9. 65-66.; Uő: „Szászy-Schwarz Gusztáv a jogtudós” JK (régi sor.) 1933/47. 269 270.; HaLÁsz Aladár: Szászy-Schwarz Gusztáv és a jogalany. Kandidátusi értekezés. (Budapest: 1957). Nekrológok: SzLadits Károly: „+Szászy-Schwarz Gusztáv” JK (régi sor.) 1920/9. 65-66.; „Nagy Ferencz gyászbeszéde Szászy-Schwarz Gusztáv ravatalánál” JÁ 1920/5. 185-188.

${ }^{40}$ A ,juristische Entdeckung" kifejezéshez többek között a jheringi tézis kapcsán lásd Hans DöLLE: „Juristische Entdeckungen, Festvortrag” in n. n.: Verhandlungen des 42. Deutschen Juristentags in Düsseldorf, 1957 (Tübingen: Mohr 1959) Bd. II, Abt. B, 1. 
(utóbbi jelentős pendant-ja az általános rész mellőzése a hazai kódexekből, mely kapcsán a kodifikátor mintegy legyőzte a pandektistát) és az alanyi jog tanáról szóló nézetek elemző értékelésére. ${ }^{41}$ Kárpótolhat azonban a korpulens, a hétköznapi Jheringet is elérhető közelségbe hozó Szászy-Schwarz-portré, hiszen - miként a Tanítvány kifejtette - jóllehet sem az iskolateremtés, sem a nagy tervek befejezése nem volt jellemző a Mesterre, mégis, ha „nevét kitöröljük, egy darab föld inog a lábunk alatt és egy darab mennyezet a fejünk fölött: ahol állunk és ahova nézünk” ${ }^{42}$

\subsection{SZLADITS KÁROLY}

Szladits Károly (1871-1956; 81-96. o.) ${ }^{43}$ életpályájának vázlata és a jelentős életmủ illő méltatása között a Szerző röviden összefoglalja a polgári baloldali beállítottságú Szladits politikai szereplésének három kínos, olykor egyenesen dicstelen momentumát (82-83. o., ill. 83. o. 8. és 10. lj.). Ezek: a Károlyi-kormányba történő be nem kerülés körülményei, ${ }^{44}$ valamint a tanácsköztársaság idején és a népbiztosok perében tett (nem tett ${ }^{45}$ ) nyilatkozatai, illetve az MTA 1949. évi XXVII. törvénnyel szovjet típusú akadémiává való átalakításával (a Szerző „részbeni önfeloszlatás”nak nevezi; 83. o. 10. lj.) foglalkozó, ún. „összes-ülés” rangidős osztályelnökként történő levezető elnöklését (a beteget jelentett Kodály helyett), amelyhez érdemes itt hozzátenni a megnyitóbeszéd tanulságos részletét. ${ }^{46}$

${ }^{41}$ A Szerző másutt tárgyalta vagy érintette e kérdésköröket, de ezek az írások kifejezetten nem a Szászy-Schwarz-i „prizmájú” pandektisztika absztrakcióinak értelmezéseként vagy kritikájaként születtek. Vö. pl. VÉKÁs Lajos: „A diszpozitív szabályozás elve és az elv kérdőjelei a gyakorlatban” MJ 2018/7-8. 385-391.

42 Idézet a 76. o.-ról.

43 Újabban RÉvÉsz T. Mihály: „A magánjog »állócsillaga«: Szladits Károly - a jogtörténész szemével” Jog Állam Politika Különszám 2020. 177-184.; HAmzA Gábor: „Emlékezés Szladits Károlyra (1871-1956), halálának évfordulója alkalmából” Jogtörténeti Szemle (a továbbiakban: JSz) 2016/2. 86-89.; Szabó Béla: „Szladits, Károly” in Stolleis, i. m. ${ }^{2} 2001,618-619$. (= $\left.{ }^{1} 1995.603-604.\right)$; TAKÁcs Péter: „»Most már nincs magánjog, nincs közjog, szüntessék be az előadásokat! « Szladits Károly tanúvallomása a népbiztosok perében (1920)” JSz 2018/3-4. 97-104. A régebbi irodalomból lásd pl. Nizsalovszky Endre: „Szladits Károly 1871-1956” MT 1956/4-6. 271-274.; Uő: „Szladits Károly egyetemi tanár” JÁ 1917/3-4. 256-257. Nekrológok pl. Weltner Andor: „Szladits Károly” Állam és Igazgatás 1956/6. 356-357.; n. sn.: „Szladits Károly 1871-1956” JK 1956/6. 321-322.

${ }^{44}$ A Szerző arra a következtetésre jut, hogy Szladits miniszteri dezignációja a „forradalmi pillanatokban jellemző sajátos véletlenek logikája” és a politikai orientációból fakadó személyes kapcsolatok működése körében keresendő, jóllehet az már-már rejtélyes. Majd idézi Károlyi visszaemlékezését, mely szerint Jászi ajánlotta figyelmébe az igazságügyi tárcára. Érdemes lett volna talán Bánffy szarkasztikus visszaemlékezését is felhívni: „Károlyi Mihály nem talált igazságügy-minisztert a kormányába, József főherceghez menet véletlenül találkozott a siklóban a professzorral, aki az improvizált felkérést elfogadta. A siklóból kiszállva az akkor megjelent újságból értesültek [Károlyi szerint csak a palota előcsarnokában (hiv. VÉkÁs, 82. o.)] Tisza István meggyilkolásáról, majd mire a főherceghez érkeztek, tapasztalták, hogy már megint nincs igazságügy-miniszter, mert Szladits Károly elpárolgott.” (kiem. tőlem.) Idézet Bánffy Miklós: Emlékeimből. (Kolozsvár: Erdélyi Szépmíves Céh 1932). Ormos könyve nyomán idézi TAKÁcs, i. m. (előző lj.), 103. o. 17. vj.

${ }^{45}$ A Szerző itt nagyvonalúan átlép a tanúvallomás jól körvonalazható ellentmondásosságán. Ehhez s a kihallgatási jegyzőkönyv szövegére nézve lásd TAKÁcs, i. m. különösen 97-99.

${ }^{46}$ Mivel a Szerző láthatólag fontosnak tartja minden releváns kérdés aktualizálását, érdemes idézni az 1949. október 31-én megtartott „összes-ülés” Szladits által elmondott megnyitó beszédéből (idő- 
Ezek az epizódok is alátámasztják: az okosság mellé a bátorság sarkalatos erénye nem egyformán méretik, hiszen a történelmi helyzetekben csupán két dolgot nehéz jókor, az erényt megőrizve kimondani: az „igen”-t és a „nem”-et. Szladits esetében a történetírás rögzítette a maga példáit, ezek azonban a hatalmas életművet nyilvánvalóan nem „deklasszálták”.

A tudományos munkásság összefoglalása (84-94. o.) körében a Szerző bemutatja a „Vázlat” (kétkötetes tankönyv) végleges formájának kialakulását. Elemzése (86-89. o.) nyomán láthatóvá válik, hogy a Glosszákban a „Kötelem jogalkata” című fejezethez írt magyarázatok négy összefüggő kérdése (a kötelem alaphatásai, a kötelmi kötelezettség tartalma, a korlátozott felelősség és a természetes kötelmek) nyomán miként válhatott a grosschmidi alapgondolat a mai kötelmi jogunk alapvető fogalmait meghatározó forrássá. A Szladits szerkesztette hatkötetes kézikönyvről a Szerző vallja: az „a magyar polgári magánjog máig legjelentősebb, tudományos igényű összefoglalása” (89. o.), melynek Szladits által írt, az általános tanokról szóló része a szerkezeti beosztás tekintetében ma is nyilvánvaló és definiatív befolyást gyakorol a magánjogi gondolkodásra. Normatana körében a Szerző vizsgálja a diszpozitív és permisszív jogszabály közti különbségtételt, a norma szerkezettana köréből pedig kiemeli Szladits dualista megközelítését azzal, hogy egyenesen „meglepő”-nek mondja, hogy a tényállás és a joghatás mellett Szladits a jogalanyt és a jogtárgyat a magánjogi szabály „logikai részének” tekinti. Ha azonban meggondoljuk, hogy mind a jogalany, mind a jogtárgy szükségképpen revelálódik mind a hipotézisben, mind a joghatásban, akkor ez a megközelítés nem tủnik problematikusnak. Egy analógia: a mondat funkcionálisan mondatrészekből áll, a mondatrészek azonban egyidejüleg bizonyos szófajok körébe is sorolandók. A Szerző kifejti, hogy Szladits a magánjogot 1941-ben a magángazdálkodás vagyonjogának látta, melynek „szférája a közjogi elemek betódulása következtében megszűkülhet ugyan, de ami belöle megmarad, az fogalmi szükségszerűséggel egyéni érdekvédelem" ${ }^{47}$, hiszen a magánjog sok vihart látott, évezredes törzse „erős gyökerekkel ül az emberi lélek mélyén, amely végsősorban mindig az egyén érvényesülésére törekszik" ${ }^{48}$.

A fejezet végén a szladitsi magánjogi iskola tagjainak körét a Szerző tág és szűk értelemben határozta meg (94-96. o.), előbbi alatt értve azokat a kiforrott, inkább a példakép Grosschmid híveinek számító jogtudósokat, akik Szladits kezdeményezésére csatlakoztak szerzőként a Glosszákhoz, valamint a magánjogi kézikönyv, a „nagy-Szladits” szerzőit. Szűkebb értelemben tekinti discipulusnak a szeminárium tagjait, akik jelentős, a szemináriumi kiadványsorozatban megjelent intézmény-feltáró alapkutatásokat végeztek, tudományos igénnyel szemlézték a bírói gyakorlatot

szerűsége magyarázatot nem igényel): „Szerencsénkre az irányadó tényezők megértő jóindulata elkerülni óhajtja a reformok oktrojálását és szívesen látja, ha az Akadémia a szükséges változtatásokat alkotmányosan, a jogfolytonosság útján, az alapszabályok módosításával maga hajtja végre. Ennek megfelelően az Akadémia részéről kiküldött külön bizottság gondos előkészítés után megszövegezte a módosított alapszabályok tervezetét, melyhez az igazgató-tanács máris hozzájárult és amely jelenleg az összes-ülés előtt fekszik, megvitatás és határozathozatal végett." (kiem. tőlem.) Lásd: Akadémiai Értesítő LVII. kötet (1949-50), 481. füzet (Budapest: MTA 1950) 5.

47 Szladits Károly (szerk.): Magyar magánjog. I. kötet, Ált. rész, 37-38.

${ }^{48}$ Szladits, i. m. (47. lj.) I. kötet, Ált. rész, 110. 
és a szakirodalmi irányokat (bibliográfiák készítése). Ide számítja a Nizsalovszky által vezetett szeminárium sorozatában monográfiával jelentkező Eörsit (1947) és a Szladits-Festschriftek (1937, 1941) szerzői közül Világhyt, akik később jurátusok generációinak adták tovább az ideológia által elsüllyesztendőnek ítélt szellemiséget és tudást, mely a Szerző szerint „némileg korrigálta a mostoha kor ideológiai elfogultságait és butító téveszméit”. (72. o.)

\subsection{NIZSALOVSZKY ENDRE}

Nizsalovszky Endre (1894-1976; 97-111. o.) $)^{49}$ előmenetelét és kodifikátori tevékenységét összefoglaló pályaképi vázlata elején a Szerző arra utal, hogy a tudós személyiségének portréját a Nizsalovszky-emlékkönyvben (1994) megjelent Mádlféle „arcképvázlat” nagy empátiával festette meg, ezért ehelyütt inkább a szakmai életmű értékelését tűzi ki célul.

Szükségesnek látszik azonban két olyan további személyes „pillanatkép” (az elsőt Mádl idézi, a második alkalmasint új) felmutatása, mely megvilágítja a humanum iránt is érzékeny, az ideologikus fogalomhasználat nyomásának olykor túlzottan engedő és emiatt komolyan vívódó tudós személyiségét. A jó célért vállalt, okos kompromisszum modus vivendije több helyütt megjelenik az 1956. október 22-én, az MTA ÁJTB ülésén elmondott, Mádl által a családi kézirattárból hivatkozott beszédben. Így pl. elsőként talán Nizsalovszky száll síkra egy méltó nemzeti címerért: „[a Rákosi-címerrel a] „mienk a legnemzetietlenebb nemzeti jelvény [...,]” ha a címer hagyományos elemeinek legalább egy részét visszaállító új címer alkalmazását úgy rendelné el a törvényhozás, hogy két évi átmeneti idő alatt még a régit is szabad használni [...], az Alkotmányban leírt jelenlegi címer hetek alatt eltűnne az országból”. A másik „pillanatkép” a Nizsalovszky-bibliográfia ${ }^{50}$ pontosítása $^{51}$ által tűnik elő. A katolikus világi hívek XI. Piusz pápa (1922-1939) buzdítása nyomán világszerte nemzeti keretek között létrejött mozgalma, az Actio Catholica kulturális szakosztálya 1946-ban „A demokratikus közélet katolikus megvilágításban” címmel ankétot szervezett. A demokratikus közélet lényeges témaköreit átölelö, szinte profeti-

${ }^{49}$ EöRsi Gyula: „Nizsalovszky Endre” MT 1977/4. 313-315.; BALoGH Judit: „Nizsalovszky Endre habilitációja a Debreceni Tudományegyetemen (1929)” in GoszTonyı Gergely - RÉvÉsz T. Mihály (szerk.): Jogtörténeti parerga II. Ünnepi tanulmányok Mezey Barna 65. születésnapja tiszteletére. (Budapest: ELTE Eötvös Kiadó 2018) 27-33. Uő.: „Nizsalovszky Endre (1894-1976)” in Szabó Béla (szerk.): „Ernyedetlen szorgalommal ... ”. A Debreceni Tudományegyetem jogász professzorai (1914-1949). (Debrecen: DE ÁJK 2014) 441-466.; NizALowsKi Attila: „Újabb adalék Nizsalovszky Endre portréjához” Iustum Aequum Salutare (a továbbiakban: IAES) 2014/2. 199-203.; Uő: Nizsalovszky Endre: „Dologi jog - egy régi törvénytár mai tanulságai” MJ 2001/5. 316-320.; MenyнáRd Attila: „Nizsalovszky Endréről” in Hamza Gábor (szerk.): Az Eötvös Loránd Tudományegyetem Állam- és Jogtudományi Karának évkönyve 2006. (Budapest: ELTE ÁJK 2007) 381-384. Nekrológ pl. MádL Ferenc: „Nizsalovszky Endre (1894-1976)” JK 1977/1. 1-3.; EöRSI Gyula: „Nizsalovszky Endre (1894-1976)” MT 1977/4. 313-315.

50 Nizalowski (KovÁcs) Attila: „Bibliográfia” in VÉKÁs Lajos - MÁdL Ferenc (szerk.). Nizsalovszky Endre Emlékkönyv. (Budapest: ELTE ÁJTK 1994) 297-307.

51 Abban ugyanis kiadási évszám nélkül szerepel az itt bemutatott, valóban é. n. megjelentetett kötet. 
kus előadások ${ }^{52}$ anyaga (ugyanezen cím alatt) könyv alakban is megjelent (1947), szerkesztője és a terjedelmes előszó szerzője Nizsalovszky volt ${ }^{53}$ (érdemes a szerkesztői fülszöveget ${ }^{54}$ átfutni).

A katedrával vagy anélkül is tanár tudós - a kutatott területek nagyfokú diverzitása folytán sokszínű - portréja élénken áll az olvasó előtt Mádl interpretációjában. Mádl a tudomány iránti alázatnak tulajdonítja Nizsalovszky kivételesen gazdag recenzeáló tevékenységét, ${ }^{55}$ érdemes azonban talán arra is utalni, hogy e nagy igénybevételt jelentő munka iránti elkötelezettség a politikai eszközökkel kiirthatatlan tanár-szellemiségből is forrásozhatott.

A tudományos munkásság körében a Szerző értékeli és aktualizálja a hiperinflációs időszakban a valorizáció (a magánjogi pénztartozások átértékelése) és a jelzálogjog kérdését rendező jogalkotói, kommentátori és összehasonlítójogi munkásságot, illetve a grosschmidi „Fejezetek”-hez a korlátolt dologi jogok témakörében füzött, a jelzálog dologi létfolyamatát elemző glosszát, amely a Szerző álláspontja szerint jól kiegészíti Grosschmidnak az e tárgyban már hatályon kívül helyezett Optk.-t tárgyaló, kötelmi jogi vizsgálódásait. (100-104. o.)

Nizsalovszky legnagyobb külföldi elismerést kiváltott műve a család jogi rendjének alapjait elemző, magyar és angol nyelven is publikált monográfiája, amellyel összefüggésben - Vékás jól elhelyezett hangsúlyai (104-109. o.) alapján - tanúi lehetünk annak a már-már „én-idegen” jelenségnek, hogy a német jogirodalom egyfelől kifejezze: a magyar jogfejlődés befolyásolta a németet (közszerzemény), másfelől ne cáfolja a magyar (szocialista) családjog nyilvánvalóan ideológiai okból felsőbbrendűnek állított voltát, amely többek között azon alapult, hogy a német szabályozást a magyar a férfiak és a nők, illetve a törvényes és a házasságon kívül született gyermekek egyenjogúsítása terén egy évtizeddel megelőzte. Vékás finom elemzése nyomán az is világossá válhat az olvasó számára: a családjog önálló jogág voltának igazolása itt nem a szocialista jogtudomány ideologikus ${ }^{56}$ manírja álszakmaisággal leöntve, hanem komparatív jog- és társadalomtudományi elemzés, amely a szocialista vagyoni viszonyok szegényessége és e jogterület döntően személyi jel-

52 Témakörök: a keresztény társadalombölcselet, a „korszerü”, a politikai, a szociális és a gazdasági demokrácia, a szabadságjogok, a társadalmi szervezetek és az állam, a mezőgazdasági termelés újjászervezése.

${ }^{53}$ NizSAlovszky Endre: Előszó. In: Uő (szerk.): Kereszténység és demokrácia. (Budapest: Szent István Társulat é. n.) 3-10. A kiadási évszámra az irodalmi mũvek ajánlását tartalmazó püspöki körlevelekből lehet következtetni; lásd pl. Virág Ferenc, pécsi püspök 276/1947. sz. körlevelét in Litterae circulares ad venerabilem clerum almae dioecesis Quinque-ecclesiensis dimissae anno Domini 1947. (Pécs: Taizs 1947) 4. Forrás: https://archivum.pecsiegyhazmegye.hw/images/PEL.I.1.f.1_1947.pdf.

54 „Katolikus férfiaknak az Actio Catholica országos központjával kapcsolatban álló, tudományos mủveltségű csoportja egy évvel ezelőtt komoly lelkiismeretvizsgálatot végzett. Bizalmas megbeszélések során súlyos kérdésekkel kívántak fenntartás nélküli őszinteséggel szembenézni. A keresztény humanitás eszméjével ellentétben álló és az országot végveszélybe döntő, a közelmúltban uralmon volt ideológia megbukott. De vajon katolikus meggyőződésük feláldozása nélkül mennyiben tehetik magukévá azokat a vezérlő gondolatokat, amelyek ennek szétrombolása után a magyar állami, társadalmi és gazdasági rend újjáépülése körében olyan nagy szerepet töltenek be. [...]”

${ }^{55} \mathrm{Az}$ Emlékkönyvben megjelent, Mádl-féle portrét idézi a Szerző (100. o.).

${ }^{56}$ Lásd általánosságban pl. JАКАB András: „A szocializmus jogdogmatikai hagyatékának néhány eleméröl” IAES 2007/1. 189-214., különösen 208-212.; konkrétan pl. WEISS Emília: „Az új Polgári Törvénykönyv és a családjogi viszonyok szabályozása” Polgári Jogi Kodifikáció 2000/2. 4-13. 
lege folytán nem elsősorban politikai ideológiai alapon igazolja annak a polgári jogtól külön kezelendő jellegét.

A tudósok prófétai látásmódjának feltétele nem a jóslás - abszurd - készsége, hanem a többségből hiányzó, különleges tehetség a lényeg meglátására. Idetartozik a következő idézet a magánjogi monizmusról: „a magyar jogalkotót [...] évtizedek választják el attól, hogy szükséges legyen választania a kereskedelmi jogias megoldás és a polgári jog belső egysége között” - írta Nizsalovszky az állami vállalatok forgalmi viszonyairól az ún. „új gazdasági mechanizmus” (a továbbiakban: ÚGM) küszöbén. ${ }^{57}$

Az octogenarius Michelangelo, Verdi és Rameau alkotói termésére utalva mutatja be a Szerző a kutatásból nem kiszorított Nizsalovszky hetvenes éveiben elvégzett sokszínű, nagy volumenű és korát olykor évtizedekkel megelőző, praecursori produktivitását, amidőn azt írja: „A külvilág és az utókor rendszerint inkább kész a csodagyerekek, mint az idős alkotók teljesítményének rendkívüliségét értékelni; pedig az utóbbiban nem kevésbé a teremtői kegyelem megnyilvánulását kell tisztelni." Vallomás-e ez? Nem, inkább: hálaadás. ${ }^{58}$

\subsection{VILÁGHY MIKLÓS}

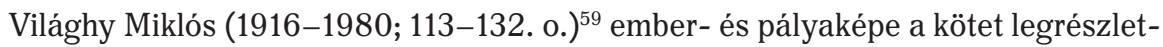
gazdagabb és legmelegebb hangú fejezete. A műben a Grosschmidről szóló (leghosszabb) rész mellett ez a fejezet az egyetlen, amely hat alfejezetre osztott: ebböl a személyes hangot prognosztizáló részek száma három (a személyiségről szóló és az értékelő részt még egy „személyes hangú epilógus” is követi), mindazonáltal a pályaképről, a tanári működésről és a tudományos munkásságról szóló, elsősorban a „szárazabb” objektivitást előlegező alfejezeteket is át-átszövi a tisztelet és mondhatni - a szeretet szavával megszólaló személyes epizódok közlése, mely nem véletlen, hiszen tanár és tanítvány viszonya keretezi a képet. A Szerző ugyanakkor nem tartózkodik sem a szakmai kritikáktól, ${ }^{60}$ sem az emberi jellemrajzot jobban árnyaló, előnyösnek nem mindig mondható részletek közlésétől, jóllehet mindenkor gondosan ügyel a történeti kontextusra - a kötetben több helyütt vallja: historia est magistra vitae -, és mind a szakmai, mind az emberi „levitas”-t, ahogyan természetesen az azzal sokszor, különösen a nehéz történelmi helyzetekben kéz a kézben együtt járó61 „gravitas”-t is, az anakronizmus tudatos elkerülésével festi meg.

${ }^{57}$ Lásd: Állam- és Jogtudomány (a továbbiakban: ÁJT) 1968/4. 517-544., 544. Idézi VÉKÁs, 98-99. o.

${ }^{58}$ Hogy is írt Vörösmartyról születése 140. évfordulóján Szerb Antal? „[...] amikor magáról beszél, akkor sem beszél magáról, de néha amikor másról beszél, lopva és óvatosan belérejt versébe valami mélyröl felszakadó vallomást.” Lásd Szerв Antal: „Vörösmarty Mihály” Új Idők 1940/49. 659.

${ }^{59}$ Nekrológok: Weiss Emília: „Világhy Miklós” Egyetemi Lapok 1980/3.; AsztaLos László: „Világhy Miklós” MT 1980/10. 777-779.; KuLcsÁR Kálmán: „Világhy Miklós 1916-1980” JK 1980/4. 201.

${ }^{60} \mathrm{Pl}$. a gazdasági jog elvetése körüli kritikák mellett a pénzintézeti és nagyvállalati szféra államosításával összefüggő jogalkotás kritikája arra hivatkozással, hogy az államositás tárgya nem a társaságok részvénye, hanem maga a vállalat mint egész volt, s ezért a reverzibilitás megszünt.

${ }^{61}$ Ilyen pl. 1948 után az egyetemi katedra választása, jóllehet a régi professzorok politikai okból történt erőszakos eltávolításának is köszönhetően; a gazdasági jog elleni, akkoriban bátorságot igénylő fellé- 
Világhy jogtanári pályarajzában hangsúlyos elemként szerepel a szóban és írásban egyaránt megnyilvánuló logikai feszesség, csiszolt stílus, tiszta fogalmazás és a vizsgáztatói szigor mellett az, hogy a hallgatók figyelmét nem anekdotikus elemekkel s nem is különös jogeseti tényállásokkal volt képes megragadni, hanem a legnehezebb módon: a nagy elméleti, rendszertani és dogmatikus kérdések értő elemzése által, amely bizonyára abban a pedagógiai érzékben és törekvésben is gyökerezett, hogy a tapasztaltabb és képzettebb elme igyekszik belehelyezkedni a mindenkori 19-20 évesek gondolatvilágába, és hozzá szellemi értelemben - a helyzettől függően - mintegy odahajol. A Szerző hangsúlyozza, hogy Világhy nem „futott el” a jogintézmények téves átideologizálásának nyílt szakmai kritikája elöl, ha azt szükségesnek látta akár a „feudális csökevény”-nek (pl. ági öröklés), akár a „veszélyes burzsoá kilengés”-nek (pl. generálklauzulák) kikiáltott intézmények védelme terén.

Világhy sajnálatosan korai, súlyos betegsége következtében idejekorán bekövetkezett halála miatt tudományos munkássága mindössze három évtizedre terjedt ki. Ennek vázrajza a fejezet bő hatvan százalékát teszi ki (117-129. o.), és hét alpontra osztott:

- a sikeres „szárnypróbálgatások” Szladits ünnepi köteteiben: már hallgatóként a tulajdonjog-fenntartásról (1937), bírósági fogalmazóként a mandatum agendiről (1941);

- a gazdasági jog léte, nemléte, mibenléte körüli heves ideológiai és jogtudományi csatározásokban való részvétel először a gazdasági jog mellett (1950), majd utóbb (1951) ellene: ez esetben - miként a Szerző rávilágít - külső (szovjet), véráldozatot is követelt „tekintély”-re hivatkozással, illetve a magyar és a szovjet társadalmigazdasági helyzet lényegi, objektív eltéréseit tekintetbe nem véve;

- jogpolitikai és -történeti jelentőségű érvelés egy polgári jogi kódex megalkotása mellett a kodifikáció alapkérdéseiről szóló, az 1953-as „fordulat” után, a gazdasági jog kodifikációjának elvetését követően csírázni várt, valódi áru-pénzviszonyokra tekintettel írt tanulmányban (1953/54);

- kiterjedt jogtörténeti és alapos összehasonlítójogi elemzéssel alátámasztott, a korszakban előfutárnak tekinthető, a jogágak önállóságának ideologikus kérdésén túllépő tanulmány (1954) a készülő új polgári jogi kódex alapkérdéseiről, úgy mint: a törvénykönyv rendszere, belső szerkezete, tárgyi-tartalmi keretei, illetve az általános rész mellőzése (Szászy-Schwarz érvrendszerébe ágyazva);

- ugyancsak a kodifikáció előkészítése körében a birtoktan és birtokvédelem alapjait lerakó, a történeti és kortárs jogösszehasonlítás eszközét alkalmazó tanulmány (1958), melynek lényegi elemei: a birtokfogalomnak a birtokvédelem elvi alapjából történő meghatározása, a birtokdefiníció objektivizálódása és a dolog feletti hatalmakat abszorbeáló kiszélesedése, a detentio elvetése, a birtok normatíve védett, tényleges hatalmi jellege, (savignyánus) érvelés a birtokvédelem önhatalmat viszszaszorító, a possessorius védelmet alátámasztó indoka körében;

pés; az 1957-ben ellene lefolytatott fegyelmi eljárás, rektori felmentés és írásbeli megrovás az egyetemi autonómia-törvény tervezetében „ellenforradalmi” nézetek érvényre juttatásának javaslata miatt, a rektori lemondás és az egyetemi vezetés átengedése a forradalmi bizottságnak, a forradalom elbukása után a letartóztatott hallgatók mentése, majd a levitas: asszisztálás a fegyelmi eljárásokban. 
- az 1988-ban indult, valódi gazdasági rendszerváltást jóval megelölegező tanulmánysorozat (1967-68) az ÚGM polgári jogra gyakorolt hatásairól amellett érvelve, hogy a gazdasági fejlődés motorjának beindításához a piaci, illetve az áru- és pénzviszonyok intenzifikálása elengedhetetlen; a sorozat Vékás által kiemelt három témaköre: az állami vállalat tulajdonosi helyzete és jogi személyisége, a tervszerződés intézményének kiüresedése, valamint a növekvő kockázatok viselése és a felelősségi alakzatok kapcsolata;

- az áruviszonyok és a szocialista polgári jog kapcsolatát elemző, a polgári jog egységességét kimutatni célzó tanulmány (1968), amelyben az árutulajdon fogalmát a végletekig kiszélesíti, eszerint: a személy elvont kategóriája az árutulajdonosi minőség absztrakciója, illetve az ún. elkülönítő hatás miatt az árutulajdon jelen van mind az állami és szövetkezeti, mind a személyi tulajdonban, melyek alapján az áruviszonyokra jellemző, sajátos polgári jogi szabályozási módszer kiterjesztendő a személyi és az egyéb nem vagyoni viszonyokra is.

Vékás Lajos Világhy-portréjából az 1959. évi Ptk. inspirálása, a kétkötetes, évtizedeken át mintegy „egyeduralkodó” tankönyv és a klasszikus magánjogi kultúra „ellenszélben” történő, rendületlen átadása nyomán kontúrt nyert szellemi nagyság mellett a lényeglátásban, az igazságkeresésben s olykor a bátorságban rejlő gravitas egyértelmủ túlsúlya látszik kirajzolódni azzal, hogy a tanítványi hủség és az atyamester iránti szeretet arra indította a „festőt”, hogy vásznára a vívódó, sőt a betegség és a szellemi-érzelmi magány totalitásában szenvedő lélek sötét tónusait is (Ady, Arany, Csoóri és Thomas Mann fájdalmas, súlyos szavaival) feltegye. Vigasztaló volt olvasni, hogy a vallottan elfogódott Szerzőt a pályán elindító, legkedvesebb tanára számára mindig ott lehetett szellemi-érzelmi menedékül W. A. Mozart muzsikája és talán a budai ciszterci gimnáziumi években Rajeczky Benjámin hatása nyomán: a gregorián. A zeneértő tanítványnak ez bizonnyal egészen transzcendens megnyugvást adhat - jó okkal. ${ }^{62}$

\subsection{EÖRSI GYULA}

Eörsi Gyula (1922-1992; 133-153. o. ${ }^{63}$ mint „sziporkázó”, a hallgatóságát „személyisége kisugárzásával” (153. o.), előadása tartalmasságával és szellemességével „lenyűgöző” (153. o.) jogtanár, mint „a zseniálisan tehetségesek megszállott szor-

${ }^{62}$ Karl Barth, a XX. századi keresztény teológia egyik legnagyobb alakja írta valahol Mozartról - aki a legenda szerint valamennyi művét odaadta volna a nyolcszáz éves húsvéti örömének (Exsultet) első gregorián soráért: „[...] Nincs szándékában Isten dicséretét hirdetni, de ténylegesen azt teszi. Meghallgattatja velünk azt, amit ő hall, azt, ami Isten jónak teremtett világából benne felszökell.” Egy Mozarthoz írt képzeletbeli levélben Barth így fogalmaz: „Nem vagyok biztos, hogy az angyalok, amikor éppen Istent dicsérik, Bach zenéjét játsszák-e, de abban biztos vagyok, hogy amikor az angyalok egymás között vannak, Mozart zenéjét játsszák, és a jó Isten is nagyon szívesen hallgatja ilyenkor őket.” Idézi Nemeshegyi Péter: „Isten szeretetének muzsikusa: Mozart” Távlatok 2006/71. 77-80., 78.

${ }^{63}$ György Kálmán: „The Problematics of Economic Law in the Works of Gyula Eörsi” Acta Juridica Hungarica (a továbbiakban: AJH) 2002/1-2. 23-41., https://doi.org/10.1556/ajur.43.2002.1-2.2; LANDI Balázs: „Eörsi Gyula polgári jogi felelősségi rendszeréről: ... az azóta eltelt három emberöltő 
galmával és fegyelmezettségével” (134-135. o.) rendkívüli hatású és méretű (136. o.) életművet alkotó jogtudós, mint a bő fél évszázadon át hatályban volt Ptk. meghatározó kodifikátora s mint a bécsi nemzetközi vételi jogi egyezményt megalkotó diplomáciai konferencia méltán világhírű elnöke (151-152. o.) „[a] kora szabta korlátok között is [...] a XX. század második fele magyar jogtudományának legnagyobb hatású alkotója, [...] aki a szellem napvilágát ragyogtatta be az Egyetem tér egyébként bizony meglehetősen szürke falai közé[; ...] az egyéniséget megtörő korban a szellem és a szép iránti hitet táplálta hallgatóiba[; ...] életművének sorsa a legnagyobbakét osztja: [...] még hosszú ideig befolyása alatt él a magánjogtudomány, és alkotó tehetségének kivételessége előtt még sokáig nem csak kegyeletből adóznak a tudományos világ és a magyar joggyakorlat képviselői." (153. o.)

Nem panegyricus-e ${ }^{64}$ (vagy: laudatio funebris ${ }^{65}$ ) ez a jellemzés? E portrérészletek magukban emlékeztethetnének Szladits Grosschmidról szóló „hozsannázó” (81. o. 1. lj.) dicshimnuszaira, azonban a Szerző „finom ecsetkezelése” a mene-tekel (Dán 5,25-28) előnytelen részleteit is felfedi (egy kivétellel ${ }^{66}$ ). Mire lett volna képes - teszi fel a nem is annyira költői kérdést a Szerző - a „magántulajdon nélküli magánjog" (133. o.) két mélyen sebző korszakhatára: az államosítás és a privatizáció között müködött Eörsi, ha az élő magánjog jutott volna alkotói periódusa hátteréül? E kérdésre a Szerző szerint az életmű mellett az 1948-as „fordulat”, az „ideológiai kényszerzubbony felvétele előtt” (134. o.) huszonöt éves korában a tulajdonátszállás problémájáról írt dolgozata alapján adható valamiféle válasz. Műveit azonban „[k]eletkezésük korának árnyai nem kis részben sötétségbe burkolják”, s a „mai olvasónak nemegyszer nagyon sok ideologikus kérget kell lehántani [...] tudományos munkáiról” (135. o.). Például már a jogi felelősségről írt műve 1961. évi „megjelenésekor sem volt érthető, hogy [...] miért kellett idézni a Szovjetunió Kommunista Pártja első titkárának [...] pártkongresszusi beszámolójából”. (135. o. 11. lj.) A tulajdonjog fejlődéséről szóló nagymonográfiáját (1951), mely vallottan „marxistává válásának dokumentuma” jellemzi „a [...] sztálinizmus ideológiájának való feltétlen megfelelés, sőt odaadás - ma már stilárisan is nagyon bántó - hangoztatása”; ezzel együtt is, írja a Szerző,

és ugyanannyi felnőtt jogásznemzedék távlatából" in Koltay András - DARÁK Péter (szerk.): Ad Astra Per Aspera. Ünnepi kötet Solt Pál 80. születésnapja alkalmából. (Budapest: Pázmány Press 2017) 535-560.; BoRoNKAY Miklós: „Eörsi Gyula és a jogrendszerek osztályozásának néhány kérdése” in FekEte Balázs - Szabó Sarolta (szerk.): „Monumentum aere perennius”. Tanulmányok Péteri Zoltán tiszteletére. (Budapest: [k. n.] 2005) 28-34.; SzÉCSÉNYI-NAGY Kristóf: „Az összehasonlító polgári jog és a jogösszehasonlítás Eörsi Gyula életmüvében” ÁJT 2010/1. 115-120. Nekrológ pl. SóLYom László: „Eörsi Gyula (1922-1992)” MT 1992/9. 1142-1143.; SÁRKözy Tamás: „Aki a tüzet ivóvízzé változtatta: Eörsi Gyula halálára” Kritika 1992/6. 19.

${ }^{64}$ Újabban lásd C. E. V. Nixon - Barbara SAYLoR Rodgers: In Praise of Later Roman Emperors: The Panegyrici Latini (University of California Press 2015).

${ }^{65}$ A panegyricus a római császárkorra az élőknek szóló dicshimnuszként rögzült müfaj. Vö. Gesine Manuwald: „Ciceronian praise as a step towards Pliny’s Panegyricus” in Paul Roche (ed.): Pliny's Praise: The Panegyricus in the Roman World. (Cambridge University Press 2011) 85-103., különösen 85-86., 92. o. 25. lj., https://doi.org/10.1017/cbo9780511920578.006.

${ }^{66}$ Lásd az Eörsi Mátyás által 2002. július 2-án a „Politikai napló” című sorozatában írtakat. Idézi: SEREG András: „Eörsi Gyula - Jogtudós álnéven” Jogifórum 2017. március 16. Forrás: jogiforum. hw/arckepcsarnok/29. 
a könyv „valószínűleg máig a legsikerültebb [...] munkának számít”. (136. o.) Vékás azonban rámutat: kérdés, „[m]ennyiben tehető ez utólag szóvá a megsemmisítő koncentrációs táborba vezető deportálástól 1944-ben csak a szerencsének köszönhetően megmenekült, és az új világban ekkor még őszintén hinni akaró [...] fiatalembernek” (136. o. 19. lj.), aki szerint a kapitalizmus ellentmondásaiból a kiút „a Kommunista Kiáltvány programjának végrehajtása” (idézi: 140. o.). Ugyanakkor - idézi (150. o. 55. lj.) szintén Eörsitől - „[a]z ember legkihívóbb riválisa a saját ifjúkori énje [...]”. A Szerző Eörsi munkásságát a fejezet kilencven százalékát kitevő (134-152. o.) II. és III. alfejezetben mutatja be, az ideológiai „kérgek” fáradságos lehántását követően összefoglalja és értékeli a bemutatott művek ma is érvényes, polgári jogi - sőt: magánjogi - gondolkodásunkra jelentős hatást kifejtő téziseit. Behatóan elemzi: a tulajdonjog fejlődéséről írt két kötetes opus-t (1951); ${ }^{67}$ a tervszerződésről (1957) ${ }^{68}$ és a polgári jogi felelősségről (1961) ${ }^{69}$ írt monográfiákat; a bírói gyakorlatot feldolgozó és a korszaktól idegen dogmatikus megközelítést mintegy mentegetőzve dicsérő, azt mégis tudatosan alkalmazó kártérítési jogi kézikönyveket (1958, 1966); a polgári jog alapproblémáiról (ti. a tárgy, a fogalom, ${ }^{70}$ a struktúraelmélet, ${ }^{71}$ az alapvető elvek és

${ }^{67}$ A tulajdonjog fejlődéséről írt, „szerencsésen komprimált, nagy európai magánjogtörténeti tabló”ról (136. o.) Vékás hiányolja ugyan az angol jog elemzését, és kifejti, hogy Eörsi zavaróan sokszor kezeli axiomatikusan az ideológiai előfeltevéseket, azonban egyszerre három lábon álló kritikával és önkritikával inti az olvasót az anakronisztikus bírálat elkerülésére: Eörsi Szászy-Schwarzcal szemben, a korhủ kontextuson belüli értelmezések gyakori hiányával összefüggésben megfogalmazott olykor ad hominem, már-már személyeskedő hangú (vö. pl. 139. o. 24. lj.) - kritikáját úgy fordítja az ideologikus premisszákból előszeretettel kiinduló Eörsi ellen, hogy e tükörben saját elmarasztaló véleménye esetleges önellentmondásait is felfedezve bírálatait nem mellőzi ugyan, hanem azokat a mű maradandó értékeire korlátozza. (137. o.)

${ }^{68}$ A tervszerződésről szóló monográfiáról Vékás megállapítja, hogy a Janus-arcú ügylet elemzése a maga korában előremutató volt - hiszen annak célja a gazdasági decentralizáció és a fennálló szerződéses rendszernek a személyes érdekek és az öntevékenység kibontakoztatása végett történő megjavítása -, napjainkban pedig a kötet elsőrangú kortörténeti forrás. Kiemeli, hogy a Eörsi már ekkor oly módon vázolta a szerződés jogintézményének alapvető, közös jellegzetességeit, amely még napjainkban is tartható.

${ }^{69}$ A felelősségről írt monográfiát - Vékás elemzését summázva - annak korabeli kritikái is túlélték: Eörsi akaratszabadságot tagadó, a teljes determinizmust valló nézete szerint a felelősségre vonás célja a társadalmi átnevelés, és a represszív szankció visszatartó ereje is csupán egy a determináló tényezők sorában. Kritikai górcsöve alá helyezi a Szerző Eörsi túl szélesre szabott, a polgári jogi felelősség egészét lényegében lefedő, de a szerződésszegésért és a személyiségsértő magatartásért való helytállást abból kizáró felróhatóság-tanát, mellyel szemben az utókor inkább Marton Géza tanait igazolta. A Szerző a problémát aktualizálja a hatályos kódexre. Az okozatosság körében Eörsi álláspontját a Szerző „reális és a gyakorlatban is használható, ha nem is egyedül üdvözítő megközelítés”-nek nevezi, mely szerint „a szankcióval befolyásolható okot lehet jogilag releváns oknak tekinteni, amelyet a konkrét esetben a bíró - mérlegeléssel - tud kiválasztani a tényszerűen oki-okozati összefüggésben lévő számtalan mozzanat közül”. (144. o.)

${ }^{70}$ A polgári jog fogalma definiálásának a kor Vékás szerint túlzott fontosságot tulajdonított. Ennek oka a Szerző szerint az lehetett, hogy a szocialista polgári jog mint „magántulajdon nélküli magánjog” meghatározása (a kiindulási paradigma önellentmondásai folytán) nagy kihívásként jelentkezett, illetőleg a „gazdasági jog meghaladottnak tekintett »réme « folytonosan ott kísértett a szerzők tudatában". (145. o.)

71 Vékás szerint sem Eörsi struktúraelmélete, sem az azzal versengő elméletek, nem voltak alkalmasak arra, hogy az állami vállalatok közötti, a vagyoni forgalom döntő hányadát közvetítő viszony mibenlétére fundált választ adjanak. 
az ideológiafüggetlen dogmatika: normatan és jogviszonytan) szóló, magyar (1965) és angol (1970) nyelven megjelent köteteket; végül a jogösszehasonlítás kérdéseire a világ egészére rálátással bíró, átfogó, de marxista választ adni célzó, ugyancsak két nyelven közzétett (1975, ang. 1979) mủvét, ${ }^{72}$ amelyre Eörsi a legbüszkébb volt. (135. o.) Eörsi komparatisztikai mủvének misszióját a megszületésekor nagy küldetést teljesített, de már önmagát túlélt, a világ bajaiért elsősorban felelős, s még óriási tartalékokkal rendelkező kapitalizmus tagadásában jelölte meg. A szerzői „credo” ellenpontjaként Vékás súlyos, de - sajnos - nem irreális kijelentést tesz (150. o.): „Ezt az ítéletet a Történelem (sic!) eddig csak egy vonatkozásban hagyta jóvá, [... abban], hogy »a kapitalizmus hatalmas tartalékokkal rendelkezik «. Ez a »fellebbviteli határozat « egyszer (félő, hogy nem is olyan távoli jövőben!) még kegyetlenebb revízió alá kerülhet, de biztosan nem olyan formában, ahogy azt Eörsi könyvében sugallja."

Végeredményben - a többihez hasonlóan - az Eörsi-portré is egyfajta korrajz, amelyben a Szerző kedvelt, Rilkétől vett ${ }^{73}$ allegorikus gondolatjátékával élve: „Mintha minden egyes részlet ismerné az összes többit."

\subsection{PESCHKA VILMOS}

Peschka Vilmos (1929-2006; 155-181. o.) $)^{74}$ jóllehet a jogviszonytani kandidatúra s majd a normatani doktori értekezés sikere után - Világhy meghívására - a polgári jog (másodállású) ny. rk., majd ny. r. tanára lett, kutatásainak súlypontja továbbra is a jogelmélet és jogfilozófia maradt, mégis, kisebb-nagyobb lélegzetủ írásaival

72 A közel hétszáz oldalas kötetben Eörsi „irdatlan mennyiségű és szerteágazó anyagot dolgoz fel; már a témák változatossága és a megközelítés sokszínűsége is zavarba hozza az olvasót. A vertikális (történeti) és a horizontális (jogösszehasonlító) módszer párhuzamos alkalmazása is nemegyszer új megvilágításba tudja helyezni a vizsgált jogintézményeket. Az olvasónak mégis komoly hiányérzete támadt már a könyv megjelenésekor [...]” (147. o.) A hiányokról csak a teljes elemzés átolvasásából kaphatunk - s akkor is csak indirekt módon - képet. Eszerint a társadalmi gazdasági folyamatok és a jog közötti kölcsönhatás alapján határozható meg a jogtípusok két fökategóriája, a burzsoá és a szocialista, előbbin belül pedig a polgári forradalmak lezajlásának közismert marxista doktrínája a jogcsoportokat kiképző erő. Vékás szerint ez a klasszifikáció - mivel a forradalmi átalakulások önmagukban még az Eörsi által döntő és közvetlen háttérnek tekintett társadalmi-gazdasági folyamatok kimerítő indokolására sem elegendők, azok még kevésbé alkalmasak az ezeknél is összetettebb oksági hátterű szabályozási folyamatok, a jogfejlődés irányai közötti, osztályozási szintű különbségtételre - egysíkú és leegyszerűsítő, azt az Eörsi által is elfogadott „finomító tényezők” sora sem csiszolja, hanem inkább áttörik a halmazok.

${ }^{73}$ Rilke Párizsból 1907. október 16-án levelet írt feleségének, Clara Westhoffnak. Az üzenetben ekképpen emlékezik meg a Salon d’Automne-ben átélt kiállítási élményéről Cézanne: „Madame Cézanne vörös karosszékben" c. portréjának megtekintése kapcsán. Részletesen lásd pl. FüLEKI Gábor: „Rainer Maria Rilke levélerdeje” Mühely 2017/2. 61-71.

74 SzILÁGy Péter: „Peschka Vilmos nyomában - korrekciókkal” JK2018/7-8. 324-333.; VARGA Csaba: „Peschka Vilmos jogfelfogása” JESZ 2018/2. 187-194.; FEKETE Balázs: „Erkölcs, etikum és jog összefüggései Peschka Vilmos munkásságában” ÁJT 2010/1. 41-49.; Prugberger Tamás: „Szintézis vagy rendszer, avagy mindkettő? Adalékok Peschka Vilmos jogfilozófiai munkásságának értékeléséhez” ÁJT 1994/1-2. 197-206. Nekrológ pl. LAmm Vanda: „Vilmos Peschka (1929-2006)” AJH 2007/1. 1-4. (és magyarul is több helyütt). 
maradandót alkotott a civilisztikában is. Terjedelmük ellenére nem paralipomena ${ }^{75}$ a következő témákat kifejtő művek: a Ptk. jogelméleti kérdései, a jogosulti késedelem paradoxona, a norma mint típus és a jogeset mint egyedi találkozása a jogalkalmazásban, a joghézag és a jogi analógia összefüggései, a fikció, a jogszabály visszaható érvényessége, a kártérítési jog válságjelenségei, a végrendelet értelmezése, valamint Nizsalovszky és Eörsi jogfilozófiájának, jogelméletének elemzése.

A pályájáról, munkásságáról és jelentőségéről szóló fejezet olvasása során az a benyomás alakulhat ki az olvasóban, hogy e portré megrajzolása nem csupán cél, hanem egyben eszköz is a Szerző számára: mintha régi óhaja teljesedne be azzal, hogy az egyetemes magánjog egyes alapvető és általános kérdéseire a nemzeti, komparatív és történeti kereteken átlépő, e módszereket meghaladó perspektívából tekinthet rá, s azokról - Peschka nyomán - jogelméleti, illetve olykor jogfilozófusi tenorban szólhat. E kérdések: a magánjog kodifikációja, Savigny és Thibaut vitája (157-162. o.); a jogfilozófia szervesülésének útja a hazai magánjogtudomány bölcseleti gondolkodásában (163-175. o.); a jogügyletek értelmezése. (175-180. o.)

Noha nem kritikátlanul, Peschka a pozitív jog létrejötte tekintetében a Szerző szerint inkább savignyánus álláspontot foglalt el azon az alapon, hogy e nézetrendszerét a korabeli Németország viszonyaira tekintettel értelmezi: Savigny jogelmélete ekként nem feudális, hanem polgári. A Szerző aktualizálja a „kodifikálni vagy nem kodifikálni” hamleti kérdését. Véleménye szerint az 1959. évi Ptk. esetében „a szokásjogról az írott jogra” (vö. 159. o.) - de talán inkább: az írott szokásjogról a törvényjogra (Gesetzesrecht) - kellett áttérni, amelynek eszköze a régi (bírói) jog formális, jogalkotói deregulációja és értelmezési tilalma volt (1960. évi Ptké. 5. §). Ezzel szemben a hatályos kódex tekintetében - eltérések: egy már létező törvényjog, illetve a bírói jog „deregulációja” nem jogalkotói, hanem legfőbb jogalkalmazói hatáskörbe telepítve - a dán királyfi örök kérdése már másként merült fel: Lejárt-e az átfogó és a nemzeti kódexek mint szabályozási formák, eszközök kora? Vékás mindkét kérdésre világos, aligha vitatható okfejtéssel nemleges választ ad. (160-162. o.)

A Szerző szerint sajnálatos, hogy Peschkának a hazai magánjog jogbölcseleti alapjait tárgyaló, egyik legjelentősebb dolgozatában (1959) kifejtett téziseire mentora, Szabó Imre burzsoá állam- és jogbölcseletről írott „katekizmusa” (1955) igen „hosszú árnyékot vetett”, vagyis álláspontja objektivitását negatívan befolyásolta, miként a kor - mely „a történelmi igazság biztos tudatában tetszelegve arra biztatott, hogy bátran kell ítélkezni elevenek és holtak felett” - nemkülönben (valamenynyi idézet: 175 o.). Peschka stílusa a Szerző szerint még így is - relatíve - visszafogott. A dolgozat mondanivalójának nem ideológiai-formális tartalmi csomópontjait Vékás számos esetben meglehetősen „ütőképes”, anakronisztikusnak nem mondható kritikával illeti (lásd a lj.-ekben). E főtémák: a feudális magánjogtudomány

75 Paralipomena tkp. a müből kihagyott, kimaradt részletek pótlólagos kiegészítését tartalmazó toldalék. 
kapcsolata kora filozófiájával (163-165. o.); ${ }^{76}$ a történeti jogi iskola befolyása (165169. o. $)^{77}$ és hazai kritikája (169-172. o.); a szociálisan érzékeny magánjogi társadalomtudomány (172-173. o. $)^{78} \mathrm{~s}$ végül a szladitsi iskola (173-175. o.).$^{79}$

A jogügyletek értelmezéséről szóló munkát a Szerző nemcsak aktualizálhatónak, de több helyütt úttörőnek ${ }^{80}$ tartja. Ama ritka esettel áll szemben az olvasó, amikor Vékás kritikai módszere nem mutat ki különösebb problémát a vizsgált tézisekben. ${ }^{81}$

„Peschka Vilmos korai halála máig nem gyógyuló sebet ejtett lelkemben. Azok közé a kiemelkedő személyek közé tartozik, akiktől a legtöbbet tanultam, nem utolsósorban életfilozófiát és emberi tartást." ${ }^{22} \mathrm{~S}$ hogy mi Vékás Lajos könyvének önmagán túlmutató értéke? Talán az, hogy sorai között ezekről is olvashatunk.

${ }^{76} \mathrm{Az}$ anakronizmus vádjával igazítja ki Vékás Peschka túlzott kritikáját abban a tekintetben, hogy a feudális kor magyar magánjogtudománya (pl. Kelemen) jól ismerte ugyan a kortárs bölcseleti tanokat (pl. Kantot), azonban még a tematikusan összefüggő részek (pl. tulajdon, szerződés, személy) tekintetében sem építette bele azokat gondolkodásába. Vékás szerint a kritika azért nem megalapozott, mert a korszak társadalmi és gazdasági viszonyai maguk is feudálisak voltak, ezért a szerzők társadalmi valóságot kifejező tételes joghoz való ragaszkodása (164. o.) aligha felróható.

77 A történeti jogi iskola tanait látszólag paradox módon nem a hazai jogbölcselet, hanem a magánjog tudománya (Wenzel, Suhayda, Zlinszky stb.) fogadta be. Vékás szerint ennek magyarázata egyszerű: az megfelelő elméleti lapot nyújtott a feudális földtulajdoni viszonyok konzerválásához; Kemény Zsigmondtól (1843) idézi: „[...] ha most Európától tetemesen különbözünk is [...], ez [...] világosan onnan foly, mert a polgárosodott állományok rég levetkezték azon formákat, melyeket mi most is csoport csalálmaink közt szeretünk bálványzani.” (166. o.) Peschka „nemzeti”-nek mondott iránynyal szembeni - ideológiai kirohanásoktól sem mentes - kritikáját Vékás azzal „veri vissza”, hogy rámutat: egyfelöl a historische Rechtsschule tanításainak zöme maga is retrográd volt, másfelöl e tényt a maga korában nem különösebben lehetett észlelni, így napjaink tisztánlátása nem alapozhatja meg a retrospektív elmarasztalást. Találóan idézi Dell’Adami (167. o.) és Grosschmid (168169. o.) igazságát.

78 Saját kritikáját feltehetően csak utólagosan - a „szocialista társadalmi rend látványos kudarcának" mai ismeretében (173. o.) - megalapozhatónak vélve mellőzi Vékás, hogy Peschkának a kapitalizmust nem eltörölni, hanem megjavítani akaró szociális jogi irányzat képviselőivel (Meszlény, Ágoston) szembeni kritikáját boncolja.

79 Szladits „liberálkapitalista” bírálatát Vékás egyszerủen azzal dezavuálja, hogy rámutat, az utókor évtizedei Szladitsot igazolták (174-175. o.). Az utólagos megítélés helyes: a tévedés már Peschka életében revelálódott.

${ }^{80} \mathrm{Az}$ „elsőség” kényes kérdéséhez lásd Alexander LüDERITz: Auslegung von Rechtsgeschäften: Vergleichende Untersuchung anglo-amerikanischen und deutschen Rechts. [=Berkeley-Kölner Rechtsstudien Bd. 8] (Karlsruhe: C.F. Müller 1966); Morten MittelstäDT: Die Auslegung empfangsbedürftiger Willenserklärungen: Eine Kritik des herrschenden Methodendualismus (Tübingen: Mohr Siebeck 2016) 113-268., https://doi.org/10.1628/978-3-16-154644-0.

${ }^{81}$ Ezek röviden: az értelmezés alanyai köréből kizárja a feleket, s az értelmezést a jogalkalmazó általi megismerési tevékenységre szủkíti; a tételesjoghoz (Ptk. 207. § és 6:8. §) képest tágabban értelmezésnek tekinti a kétségtelen, nem vitatott tartalmú, nyilatkozat vizsgálatát is; az értelmezés fogalmának és módszerének meghatározása elsődlegesen a jogtudomány, s csak kivételesen a jogalkotó feladata; a kulcsprobléma az akarat mint tartalom és a nyilatkozat mint forma közötti eltérés, melynek alapja a gondolat és a nyelv közötti gyakori inkongruencia; irányadónak - az egyaránt szubjektivistának tekintett akarati és nyilatkozati elvvel szemben - a dualista elméletet tekinti; a normaértelmezés historicus módszerét transzponálja Peschka az ügyleti interpretációra is, értve ez alatt azt az esetet, amikor a bíró a jogügylet keletkezésének - jogi és nem jogi - körülményeit vizsgálja.

${ }^{82}$ Idézet: 181. o. (kurzivált kiemelés tőlem). 


\section{EPILÓGUS}

Az Athéntól északnyugatra, a falakon kívül fekvő olajfaliget, Akadémosz földjét is emberi láb taposta. Az akadémeikoi lábnyomai szántotta barázdák a több évezredes emberi gondolkodás „földjén” azért válhattak szinte kútmélységűvé, mert a tudós „szántóvetők” az utánuk jövőket hajlandók voltak széles vállaikra véve felemelni. S akarva-akaratlan éppen ezzel állítottak maguknak örök gránitszobrot, amelyet immár - vice versa - a tanítványok generációinak válla mint talapzat emel a magasba.

„[K]orosztályunk az ő vállukon áll - vallja az elődökről Vékás Lajos -, és ha ők nem lettek volna, a mi vállunkra nem állhatnának a mai fiatalok”. (11. o.) A Szerző történelmi tablót idéző, a tudományunk kontinuitását alátámasztó mủvében a nagyszerü elődökről a képek kritikai szemléletet sem nélkülöző, részletgazdag realitása mellett azzal is maradandó - a festőt is dicsérő - portrét alkot, hogy a történelmi időkben tanúsított emberi gyengeségeket sem kendőzi el, ám azokat nem is hangsúlyozza túl, nem mentegeti, de ítéletet sem mond felettük. Az ókori humanista Terentius jambikus sorával szólva maga is mintha azt mondaná: „Homo sum: humani nil a me alienum puto.” ${ }^{83}$ Miként inti a „dallandó” ${ }^{84}$ cipészmester, Sachs, a záró monológban Stolzingi Waltert - emlékeztetve őt a mesterdalnokok történelmi szerepére?

„A zord idők alatt

Mégis igaz maradt,

S ha másként nem volt sikere, Elégedjünk meg igy vele, Mert az becsülve tartaték, A mesterektől ez elég! Vigyázz! Jövend nehéz idö: A nép, ha nem megegyezö, Sha álcélokra küzdenek, Népét a fö nem érti meg,

\author{
S mit kívülröl nyer így a nép, \\ Hamis káprázás, csalfa kép. \\ S ami honi, való s igaz, \\ Nem érti senki már, mi az. \\ Mondom azért, becsüld a mesternépet, \\ Jó szellemid ők néked! \\ S ha majdan porba sújt a sors \\ És mint a szél; eloszlik majd \\ A hös és szép birodalom, \\ De a dal, az mindig él!'
}

83 „Ember vagyok, nem idegen tőlem semmi, ami emberi” - szól az együttérző Chremes Senex Terentius „Heautontimorumenos” („Az öngyötrő”, „A magakínzó”; Kr. e. 163) c. komédiájában (I. felv. 1. jel. 77. sor). A humanista kontextushoz részletesebben lásd Eckard LEFÈvRE: „Ich bin ein Mensch, nichts Menschliches ist mir fremd" in Otto Herding (Hrsg.): Wegweisende Antike: zur Aktualität humanistischer Bildung; Festgabe für Günter Wöhrle. (Stuttgart: Verein zur Förderung der Humanistischen Bildung 1986) [=Humanistische Bildung, Beiheft 1] 39-49.

${ }^{84}$ A különleges ige, „dalland”, Arany János: „Egressy Gábornak” c. verséből (9. versszak, utolsó sor) való, s utalni kíván a zeneértő Vékás Lajos e másik, a bemutatott műben is merész analógiák képében meg-megjelenő szenvedélyére: a muzsikára. Az Arany-versben zene és komponista - hasonlóan Wagner Sachsának monológjában a dalhoz s a dalnokhoz - történelmi szerepben csillog.

${ }^{85}$ Wagner librettóját ford.: VÁRADY Antal. Forrás: http://www.tarjangz.ew/libretto/szovegek/nurnberg.txt. 